\title{
A NACIONALIDADE À LUZ DO DIREITO INTERNACIONAL E BRASILEIRO
}

\author{
Nationality in Brazilian and International Law ${ }^{1}$
}

\section{Carmen Tiburcio ${ }^{2}$}

\begin{abstract}
Sumário: 1 Definição de nacionalidade. 2 Conceito de estrangeiro. 3 Nacionalidade, naturalidade e cidadania. 4 A importância da nacionalidade. 5 Aquisição da nacionalidade. 6 Perda e reaquisição da nacionalidade. 7 Distinções entre nacionais. 8 Polipatrídia e apatrídia. 9 Competência para atribuir a nacionalidade. 10 Princípios gerais limitando o poder dos Estados em questão de nacionalidade. Referências.
\end{abstract}

\begin{abstract}
Resumo: Status outorgado àquele que possui vínculo com um determinado Estado, a nacionalidade é atrelada a direitos e deveres. O conceito é formado não apenas por elementos formais, mas também pelo sentimento de pertencimento. Partindo-se de uma definição políticojurídica, no entanto, apenas o Estado (isto é, através de seu ordenamento) pode considerar um indivíduo seu nacional. Determinado o que seja um nacional, define-se também, a contrario sensu, quem é estrangeiro frente a um dado Estado. O presente trabalho analisa a importância da matéria e suas implicações e, principalmente, os fenômenos de aquisição, perda e reaquisição do status de nacional, seus requisitos e as circunstâncias em que se produzem. Aborda-se, ainda, a questão da distinção entre nacionais originários e naturalizados e as hipóteses de polipatrídia e apatrídia. Por fim, o artigo lança luz sobre a competência para atribuição da nacionalidade e os princípios que limitam o poder dos Estados nesse tema tanto sob a ótica do direito internacional como brasileiro.
\end{abstract}

Palavras-chave: nacionalidade, cidadania, naturalização

Abstract: Status granted to those who have some link to a particular state, nationality comes with rights and duties. The concept is composed not only by formal elements, but also by the 'feeling' of being a part of a group. From a political-legal viewpoint, however, only the State (i.e., through its legal system) may consider an individual one of its nationals. After determining who is a national, one can define who is a foreigner in relation to a given state. This paper analyzes the importance of the matter and its implications, and especially the phenomena of acquisition, loss and reacquisition of the status of a national, its requirements and the circumstances on which they occur. The distinction between national and naturalized citizens and the topic regarding the hypothesis of multiple nationalities and statelessness are also discussed. Finally, the article sheds light on the responsibility for granting nationality and the principles that limit the power of the States on this issue, both under international and Brazilian law.

Key-words: nationality, citizenship, naturalization

\section{DEFINIÇÃO DE NACIONALIDADE}

A nacionalidade pode ser definida sob a ótica jurídico-política ou sociológica, embora usualmente a distinção não seja facilmente perceptível, na medida em que um significado não exclui necessariamente o outro. Na sua acepção jurídico-política, a nacionalidade pode ser definida como um status

\footnotetext{
${ }^{1}$ DOI deste artigo: http://dx.doi.org/10.12957/cosmopolitan.2014.13733.

2 Doutora em Direito pela University of Virginia. Professora associada da Universidade do Estado do Rio de Janeiro.
} 
outorgado ao indivíduo3, vinculado a um Estado por laços de lealdade4. Da definição se infere que somente pessoas físicas são titulares do vínculo, gerador de direitos e deveres e que é imprescindível o reconhecimento formal por parte do Estado5.

Em sua acepção sociológica, nacionalidade é o sentimento de fazer parte determinado grupo (Zugehörichkeit) ${ }^{6}$. Em regra, este grupo ostenta alguns atributos em comum, além da origem, tais como língua, território, instituições políticas, costumes e religião7. Veja-se que o sentimento de ser parte de uma nação, em termos étnicos, culturais ou linguísticos, pode existir antes da ligação política ser nacionalizada ${ }^{8}$, isto é, antes da criação do Estado. A ideia de nacionalidade, contudo, não compreende apenas a noção de um grupo homogêneo, animado por atributos comuns. Requer, também, a busca de sua expressão no que é considerado a maior forma de atividade organizada, o Estado soberano9. Assim, a nacionalidade é um estado de espírito que corresponde ou esforça-se para corresponder a um fato político ${ }^{10}$.

Pela comparação das definições, pode-se observar, na última, a acentuação do papel do indivíduo na relação, na medida em que se admite a existência do sentimento de nacionalidade antes mesmo da criação formal do Estado. Por outro lado, em sua acepção jurídico-política, adotada pela Harvard Research in International Law, se requer, como pressuposto da existência da nacionalidade, que a relação entre o indivíduo e o Estado seja formalmente reconhecida. Desse modo, à definição jurídico-política não é suficiente que o indivíduo se considere nacional de determinado Estado. Faz-se imperativo o reconhecimento expresso e formal do vínculo.

\footnotetext{
3 Vide Convenção do Conselho da Europa sobre Nacionalidade (1996), art. 2, a: "Nacionalidade designa o vínculo jurídico entre um indivíduo e um Estado, não indicando, contudo, a origem étnica desse indivíduo".

4 Harvard Research in International Law, Draft on Nationality, Harvard, 1929, art.1 ${ }^{\circ}$ (a). Nos comentários a esse artigo define-se nacionalidade como a ligação entre uma pessoa e um Estado, p. 22, e o laço de lealdade é o termo usado para denotar a soma de obrigações da pessoa natural para com o Estado, p. 23; Supplement to the American Journal of International Law, v. 23, 1929, disponível em: http://www.uniset.ca/naty/maternity/23AJILSS13.pdf.

5 Richard Plender, International Migration Law, 1987, p. 11. Zeballos, La Nationalité, v. I, 1914.

${ }^{6}$ Hans Kohn, The idea of nationalism, 1967, p. 12.

7 Id., pp. 13-4.

8 F.H. Hinsley, Nationalism \& the international system, 1973, p. 22.

9 Id., p. 19.

${ }^{10}$ Id., ib.. 
Paul Lagarde funde ambas as definições, atribuindo duas dimensões ao conceito de nacionalidade. Na dimensão vertical figura a ligação entre o indivíduo e o Estado ao qual ele pertence, pela qual o indivíduo tem deveres (lealdade, serviço militar, etc.) e direitos (por exemplo, proteção diplomática) ${ }^{11}$. A dimensão horizontal compreende o indivíduo na qualidade de membro de determinada comunidade, integrante do povo que forma o Estado ${ }^{12}$.

No tocante à definição político-jurídico de nacionalidade, é de se observar ainda que apenas o Estado pode outorgar ao indivíduo o status de seu nacional13. É dizer: as leis de cada Estado irão estabelecer quem será considerado como seu nacional com a exclusão de todos os demais, a despeito de terem vínculos com aquele Estado ${ }^{14}$.

Veja-se que a coexistência de ambas as definições de nacionalidade jurídico-política e sociológica ${ }^{15}$ - é plenamente aceitável. Quando um indivíduo se sente fortemente ligado ao Estado do qual é nacional, tem-se uma acepção fortalecendo a outra, ambas sustentando-se mutuamente. Um povo unido e leal gera um Estado forte, pela submissão e aprovação incondicional de suas regras.

Este interessante e importante conceito é muito frequentemente olvidado. Quando se cogita de um Estado, levam-se em conta suas autoridades, o grupo de administradores encarregados, burocratas e forças armadas, por exemplo. Por outro lado, ignora-se, frequentemente, seu povo, cuja participação ativa cumprindo as leis, acreditando e trabalhando por objetivos comuns - é elemento

\footnotetext{
${ }^{11}$ Proteção diplomática é mais um benefício do que um direito. Na verdade, proteção diplomática no exterior é um direito do Estado envolvido e não do indivíduo, na medida em que o Estado pode ou não exercer a proteção diplomática, segundo seu próprio discernimento. Conforme Borchard "The State does not give effect to the right of its citizen but to its own right, the right that its citizen may be treated by other States in the manner prescribed by international law." Diplomatic Protection of Citizens Abroad or the Law of International Claims, 1916, p.18.

12 Paul Lagarde, La nationalité française, 1975, p.1.

${ }^{13}$ Esta regra foi expressa nos arts. $1^{\circ} \mathrm{e} 2^{\circ}$ da Convenção Concernente a Certas Questões Relativas ao Conflito de Leis sobre a Nacionalidade, Haia, 1930, que prevê que cada Estado determinará, segundo suas próprias leis, quem são seus nacionais e qualquer questão sobre a aquisição da nacionalidade por determinado indivíduo de um Estado particular deverá ser definida de acordo com as leis desse Estado. Promulgada pelo Decreto $n^{0}$ 21.798/32.

${ }^{14}$ A CPJI estabeleceu que: "... the national status of a person belonging to a state can only be based on the law of that state." The Exchange of Greek and Turkish Populations, ser. B, No. 10, 1928, p. 19. 15 Vide a definição da Corte Internacional de Justiça da Haia, no caso Nottebohm: CIJ, Caso Nottebohm (ICJ Reports 1955, 4, 23): "a legal bond having as its basis a social fact of attachment, a genuine connection of existence, interests and sentiments, together with the existence of reciprocal rights and duties".

Revista de Direito Internacional do Programa de Pós-Graduação em Direito da UERJ 
basilar e imprescindível à sua efetividade e eficiência, sem o que restariam inertes e impotentes as autoridades governamentais ${ }^{16}$.

\section{CONCEITO DE ESTRANGEIRO}

A determinação da nacionalidade permite definir quem são os estrangeiros. Considera-se estrangeiro, relativamente a um dado Estado, o indivíduo que, por força de lei, não é considerado seu nacional. Trata-se, portanto, de uma definição a contrario sensu, o que leva à conclusão de que apátrida ${ }^{17}$, por exemplo, será sempre um estrangeiro, onde quer que esteja.

Duas conseqüências se apresentam: primeiramente a importância do conceito de nacionalidade relativamente à definição de estrangeiro; e, em segundo lugar, o óbvio, porém despercebido, fato de que qualquer indivíduo é um estrangeiro fora do país da sua nacionalidade. Dessa forma, é importante notar que, se a condição de estrangeiro é aplicável a qualquer um de nós, não se pode admitir, em sua definição, qualquer elemento de conotação inerentemente inferior ${ }^{18}$.

\section{NACIONALIDADE, NATURALIDADE E CIDADANIA}

Há que se distinguir a nacionalidade de dois outros conceitos correlatos: naturalidade e cidadania. A naturalidade é um conceito territorial. Quando determinado indivíduo nasce em certa cidade, diz-se que é natural desta cidade e do país no qual está localizada, sem que se possa inferir que este indivíduo seja necessariamente nacional daquele país. Entretanto, no caso dos países que

\footnotetext{
${ }^{16}$ Karl Deutsch, Nationalism and its alternatives, 1969, p. 17-9. Nas palavras do autor: "Compliance is the invisible 9/10ths that keeps afloat the iceberg of the state, and it is a vital development in the process of integration. To say that law-breakers will be punished implies that most people will not break the law because if they all did there would be no one to punish them. No law can be maintained that is not overwhelmingly backed by the voluntary consensus of the community. The consent of the governed is not an ornament of the government of the State; it is its foundation." (grifo acrescentado)

${ }^{17}$ Cada país irá definir, por lei, quem são seus nacionais. Como não se verifica uniformidade nas leis sobre nacionalidade, pode ocorrer que determinado indivíduo não seja considerado nacional de país algum, circunstância em que se lhe será atribuída a condição de apátrida.

18 McDougal, Lasswell e Chen observaram que: "the reference of the generic label 'aliens' is not to some static isolated group, but potentially to the whole of humanity. Every individual is a potential alien in relation to all the states of which he is not a national; to the extent that he moves and engages in activities across state boundaries, this potentiality becomes an actuality." Myres S. McDougal, Lung-chu Chen, Harold D. Lasswell, The Protection of Aliens from Discrimination and World Public Order: Responsibility of States Conjoined with Human Rights. In: American Journal of International Law, v. 70, 1978, p. 433. 
adotam o critério do ius solis, coincidem, em seus efeitos, os conceitos de naturalidade e nacionalidade. Como se verá oportunamente, o Brasil tradicionalmente adota este critério para atribuir a nacionalidade brasileira, de modo que, entre nós - como regra geral - os conceitos de naturalidade brasileira e nacionalidade brasileira coincidem.

Cidadania, por outro lado, é um conceito mais específico, compreendendo todos os nacionais de determinado país no gozo de direitos políticos ${ }^{19}$. Para participar da vida pública do Estado e gozar de todos os direitos políticos, o indivíduo, além de nacional, necessita ostentar a condição de cidadão ${ }^{20}$. No Brasil a regra não é diferente: o cidadão brasileiro é também nacional.

A seu turno, a nacionalidade compreende, de forma mais abrangente, aqueles indivíduos que possuem lealdade ${ }^{21}$ a determinado Estado, e se encontram, em vários níveis, sob o manto de sua proteção ${ }^{22}$. Objetivamente, os nacionais têm uma ligação especial e permanente com o Estado de sua nacionalidade, envolvendo obrigações e vantagens, como a proteção em nível internacional23 e o direito de residência. Nacionalidade é, portanto, uma relação bilateral 24 .

A linha divisória entre nacionalidade e cidadania é difícil de ser estabelecida, pois ambos os termos enfatizam diferentes aspectos do mesmo

\footnotetext{
19 Alguns autores definem como cidadão o indivíduo com potencialidade para adquirir direitos políticos. Conforme observado por Gordon \& Rosenfield, Immigration Law and Procedure, \$11.3, alguns cidadãos podem não gozar de todos os direitos políticos (crianças, mulheres, pessoas condenadas por certos crimes e, no caso específico dos EUA, residentes do District of Columbia, por exemplo). O Direito Constitucional Moderno, contudo, mantém a definição de cidadania como o status do nacional possuidor de direitos políticos efetivos. Francisco Rezek, Le droit international de la nationalité, Recueil des Cours, 1986, p. 344.

${ }^{20}$ A grande maioria dos países concede direitos políticos apenas a seus nacionais.

${ }^{21}$ Consoante observado por Gordon \& Rosenfield, Immigration Law and Procedure, o termo lealdade (allegiance em inglês) deriva da sociedade feudal e aristocrata, significando submissão e obediência. Atualmente, este termo conota geralmente lealdade e participação, ao revés de submissão.

${ }^{22}$ W. Bishop, International Law: Cases and Materials, 1971, p. 488. Vide CIDH, Opinião Consultiva n. ${ }^{\circ}$ 4/84, de 19.1.1984 ("Propuesta de Modificación a la Constitución Política de Costa Rica relacionada con la Naturalización”): “35. La nacionalidad puede ser considerada como el vínculo jurídico político que liga a una persona con un Estado determinado por medio del cual se obliga con él con relaciones de lealtad y fidelidad y se hace acreedor a su protección diplomática." (www.corteidh.or.cr/docs/opiniones/seriea_04_esp.pdf)

${ }_{23}$ No caso Panevezys-Saldutiskiis Railways PCIJ observou-se que: "in the absence of a special agreement, it is the bond of nationality between the State and the individual which alone confers upon the State the right of diplomatic protection." P.I.C.J.(1939), Ser. A/B, No.70, p.16.

24 Oppenheim, International law, vol. I, 1905, p. 645-6: "The right is that of protection over its citizens abroad which every State holds...The duty is that of receiving on its territory such of its citizens as are not allowed to remain on the territory of other States."

Revista de Direito Internacional do Programa de Pós-Graduação em Direito da UERJ
} 
fenômeno: ser membro do Estado ${ }^{25}$. Pode-se dizer, contudo, que a nacionalidade sublinha o aspecto internacional, ao passo que a cidadania, o doméstico ${ }^{26}$. Vejase que se, por um lado, todo cidadão é um nacional, o caminho inverso não é necessariamente verdadeiro ${ }^{27}$. Por regra lógica, a verificação da nacionalidade antecede, no tempo, a aquisição de direitos políticos ${ }^{28}$. Assim, embora a nacionalidade seja requisito para a concessão do status de cidadão, a atribuição de nacionalidade independe da caracterização do indivíduo como cidadão. Esse, aliás, o motivo da tradicional exclusão dos estrangeiros com relação ao gozo de

${ }_{25}$ Muitos autores não distinguem entre esses termos. Hans Kelsen, Principles of International Law, 1987, p. 372: "Citizenship or nationality is the status of an individual who legally belongs to a certain State or formulated in a figurative way- is a member of that community".

Essa confusão terminológica parece originar-se da $14^{\mathrm{a}}$ Emenda da Constituição Americana, que determina: "All persons born or naturalized in the US and subject to the jurisdiction thereof, are citizens of the US and of the State wherein they reside" e do caso EUA x Wong Kin Ark, onde a Suprema Corte interpretou esta regra no sentido de que todas as pessoas nascidas nos EUA, mesmo de pais chineses têm a nacionalidade norte-americana. Aleinikoff \& Martin, Immigration: Process and Policy, 1985, p. 833, nota 3.

${ }^{26}$ Paul Weis, Nationality and statelessness in international law, 1956, p. 5.

${ }_{27}$ Paul Weis, Nationality and statelessness in international law, 1956, p. 6. Na virada deste século, quando os EUA adquiriram territórios fora dos seus limites continentais, a Suprema Corte, no caso Downes x Bidwell, 182, US 2449 1901, adotou uma distinção entre território incorporado e não incorporado. Em razão desta decisão, pessoas nascidas em Estados incorporados eram reputadas cidadãos norte-americanos, tal como aquelas nascidas em qualquer outro Estado; indivíduos nascidos em Estados não incorporados, contudo, não eram tidos por cidadãos norteamericanos, mas possuíam lealdade aos EUA e eram seus nacionais. Gradualmente o status desses territórios foi modificado. Os filipinos tiveram sua independência alcançada em 1946; os porto-riquenhos receberam cidadania completa em 1917, alterada em 1934 e 1940; os habitantes das Ilhas Virgens em 1940 e, em 1952, pelos moradores de Guam. No entanto, os habitantes das distantes possessões da Samoa norte-americana e das ilhas Swains são ainda considerados nacionais não-cidadãos. Ver McGovney, Our Non-Citizen Nationals, Who are They?. California Law Review, 1934; Gordon \& Rosenfield, Immigration Law and Procedure; \$11.3 e Restatement of the Law Third, The Foreign Relations Law of the US, 2 volumes, The American Law Institute \$212. Section 101(a)(22) do INA determina que todo cidadão norte-americano é também nacional. Todavia, Section 308 INA outorga nacionalidade norte-americana, mas não cidadania as pessoas nascidas ou com vínculos com "an outlying possession of the United States." Essas possessões são definidas na Section 101(A)(29) INA como "American Samoa and Swains Island". Além disso, mesmo depois da introdução da $14^{\text {a }}$ Emenda, os americanos nascidos em tribos indígenas ainda não foram considerados cidadãos, não importando em que lugar dos EUA nasceram. Eles eram também considerados nacionais não-cidadãos. McGovney, idem na p. 613. Esse entendimento foi adotado pela Suprema Corte na decisão do caso Elk x Wilkins, 112 US 94, 5 S. Ct. 41, 28 L. Ed. 643 (1884). Posteriormente os congressistas norte-americanos aprovaram uma legislação superando os efeitos dessa decisão. A partir de 1940 todos os índios nascidos nos EUA são cidadãos norte-americanos. V. Aleinikoff \& Martin, Immigration: Process and Policy, 1985, p. 850 . V. Richard Plender, International Migration Law, 1987, p. 18. Ademais, conforme o direito holandês, pessoas nascidas nas possessões holandesas tinham o status de súditos holandeses (Dutch Subjects) diferentemente dos nacionais (Netherlanders). Lei de 10 de fevereiro de 1910 emendada em 10 de junho de 1927, Staatsbald, 1927, $\mathrm{n}^{\circ} 75$, art. 1, citada por Paul Weis, Nationality and Statelessness in International Law (1956). Ver Plender relativamente à nacionalidade britânica, p. 22; p. 30 para a americana e p. 34 para a francesa.

${ }^{28}$ V. Art. XXI(1) da Declaração Universal dos Direitos do Homem (ONU - Paris - 1948; Convenção Americana sobre Direitos Humanos (San José da Costa Rica - 1969), Direito Internacional Público; art. XXXVIII da Declaração Americana de Direitos e Deveres do Homem, 1948.

136 Cosmopolitan Law Journal, v. 2, n. 1, jun. 2014, p. 131-167 
direitos políticos, que pressupõem que o indivíduo seja titular de nacionalidade. No Brasil, a regra geral é que estrangeiro não goza direitos políticos ${ }^{29}$.

\section{A IMPORTÂNCIA DA NACIONALIDADE}

A nacionalidade é matéria das mais relevantes, tanto para o Estado como para o indivíduo. Para o primeiro, a nacionalidade implica a caracterização de seu elemento subjetivo. O Estado é formado por território, auto-governo e povo ${ }^{30}(\mathrm{em}$ verdade, o conjunto de nacionais), elementos sem os quais não há Estado. Por outro lado, a nacionalidade é relevante para o indivíduo, principalmente devido ao instituto da proteção diplomática ${ }^{11}$ e por diversas outras garantias que dela decorrem, tal como o direito de entrar e residir no país da sua nacionalidade.

Quanto ao ponto, a Comissão Interamericana de Direitos Humanos já afirmou que o direito à nacionalidade é um dos mais importantes direitos do homem, nos seguintes termos:

one of the most important rights of man, after the right to life itself, because all the prerogatives, guarantees and benefits man derives from this membership in a political and social community, the State, stem from or are supported by the right ${ }^{32}$.

Na Idade Média acreditava-se que a salvação não era possível fora da Igreja. Hoje seria mais apropriado dizer que, sem proteção de um Estado, sofrimentos muito maiores se verificam, a exemplo do que ocorre com apátridas e refugiados ou asilados, situação apenas recentemente incluída na esfera de interesse de determinadas instituições internacionais 33.

Como exemplo, recorde-se o drama histórico do povo hebreu, cujos membros, antes das duas grandes guerras mundiais, detinham algum poder em nível individual, porém foram incapazes de prevenir sua tragédia coletiva por não possuírem um Estado que os protegesse e defendesse suas reivindicações em nível internacional. Enquanto as leis internacionais da época, em sua maioria,

${ }^{29}$ No Brasil, contudo, os portugueses possuem alguns direitos políticos por força de tratado entre esses dois países, que concedeu direitos recíprocos aos brasileiros em Portugal e portugueses no Brasil. V. Tratado de Amizade, Cooperação e Consulta, entre a República Federativa do Brasil e a República Portuguesa, promulgado pelo Decreto $\mathrm{n}^{0} 3.927 / 01$. Frise-se que recentemente alguns países concedem direitos políticos a estrangeiros, principalmente na esfera municipal, V. Carmen Tiburcio, Human rights of aliens under international and comparative law, 2001, p. 181 e ss..

$3^{30}$ Francisco Rezek, Le droit international de la nationalité. Recueil des Cours, 1986, p. 341.

${ }^{31}$ Id., p. 346.

${ }^{32}$ Report on Chile, 1985, p.146, para. 6, apud Jaime Oraá, Human Rights in States of Emergency in International Law, 1996, p. 99.

33 Antonio Cassese, International law in a divided world, 1986.

Revista de Direito Internacional do Programa de Pós-Graduação em Direito da UERJ 
defendiam indivíduos contra Estados adversários ou inimigos, a Alemanha, sob a direção do Partido Nacional-Socialista, cometeu, por razões políticas ou raciais, atos atentatórios aos direitos humanos (como hoje os concebemos) contra seus próprios nacionais, nacionais de países aliados e contra nacionais de Estados que não se encontravam sob ocupação formal. Foram também vitimados judeus apátridas e ciganos. Naquele momento histórico, tais atos de perseguição por razões políticas ou raciais não eram proibidos mesmo em relação a indivíduos dos territórios ocupados.

Os judeus exerciam um importante papel no mundo financeiro. Investimentos de seu capital contribuíram para a sedimentação de uma função produtiva daqueles indivíduos na economia européia. Sem sua assistência, o desenvolvimento das nações-estado no século XVIII seria inconcebível34. A despeito de todo esse poder, participação e influência em diferentes áreas, os judeus presenciaram, impotentes, o crescimento do flagelo anti-semita simultaneamente na Alemanha, Áustria e França, nos últimos 20 anos do século XIX35, que ressurgiu mais forte quarenta anos depois, na maioria dos Estados europeus ${ }^{36}$. Não lhes foi possível evitar o genocídio de 6 milhões de judeus durante a Segunda Guerra Mundial: toda sua pujança econômica, influência política e cultural nada representaram diante da ausência de um Estado que resguardasse seus interesses em nível internacional.

Como se vê, a proteção do Estado - oriunda do vínculo de nacionalidade é insubstituível. A nacionalidade determinará o direito de entrada em determinado país37, e as circunstâncias nas quais tal direito poderá ser exercido38, bem como o direito de permanecer39e de trabalhar neste país, ressalvadas as limitações a que estará submetido, na condição de estrangeiro40. Relativamente

\footnotetext{
34 Hannah Arendt, The Origins of totalitarianism, 1966, p. 98.

35 Id., na p. 35.

${ }^{36}$ Id., na p. 79.

37 Um estrangeiro não tem direito de entrar em um país, enquanto um nacional de um certo país tem o direito reconhecido de entrar neste país quantas vezes desejar. Art. XIII (2) da Declaração dos Direitos do Homem - ONU - Paris - 1948.

${ }^{38}$ Em caso de uma política de quotas de imigração, o país da nacionalidade do indivíduo será de extrema importância. O mesmo pode ser dito em relação aos Tratados de Amizade entre os países ou Tratados de Dispensa de Vistos pelos quais indivíduos com nacionalidade de um dos países envolvidos poderão entrar no outro país, por exemplo, sem um visto.

39 Art. VIII da Declaração Americana, 1948 estabelece que os nacionais têm o direito de fixar residência no país de sua nacionalidade.

${ }^{40}$ Muitos países negam aos estrangeiros o exercício de inúmeras profissões. V. Carmen Tiburcio, Human rights of aliens under international and comparative law, 2001, p. 151 e ss.

138

Cosmopolitan Law Journal, v. 2, n. 1, jun. 2014, p. 131-167
} 
à retirada de indivíduos de determinado país, a nacionalidade também é determinante. Isso porque os institutos da deportação, expulsão ${ }^{41}$ e da extradição são, como regra, medidas de saída aplicáveis apenas a estrangeiros. Finalmente o status jurídico de um indivíduo pode determinar o interesse legítimo de um Estado relativamente ao exercício da proteção diplomática, uma vez que apenas o Estado da nacionalidade do indivíduo possui legitimidade para tanto a nível internacional. Veja-se que o exercício da proteção diplomática envolve todas as formas de intervenção diplomática para a resolução de disputas, amigáveis ou não, desde negociações até o uso da força ${ }^{42} \mathrm{e}$, por isso, é importante desdobramento da nacionalidade.

A possibilidade do uso da força no exercício da proteção diplomática encerra acirrada controvérsia43. A justificativa normalmente invocada é a alegação que o Estado invadido falhou no tocante às precauções necessárias ao resguardo da vida e da propriedade dos indivíduos que recebem a proteção diplomática e, por esse motivo, é necessária a tomada de medidas protetivas de tais valores, juridicamente tutelados. Mesmo após a Carta das Nações Unidas, que em seu art. $2^{\circ}$ (4) proibiu o uso da força, essa justificativa ainda tem sido utilizada,44 legitimamente45 ou não, pois muitas vezes a justificativa da intervenção externa para resgatar nacionais tem sido usada para encobrir outros motivos, como a restauração de governos depostos ou a prevenção da deposição de determinados governos.

\footnotetext{
${ }^{41}$ Ver Convenção Americana, art.22.5; art. 3(1) do Quarto Protocolo à Convenção Européia de Direitos Humanos.

${ }^{2}$ Ver Paul Weis, Nationality and Statelessness in International Law, 1956, p. 35.

43 Esta questão é examinada em detalhes por Natalino Ronzitti, Rescuing Nationals Abroad Through Military coercion and Intervention on Ground of Humanity, 1985. V. também Phillimore, Droits et Devoirs des Etats. In: Recueil Des Cours, 1923, p. 27-49.

44 Natalino Ronzitti, Rescuing Nationals Abroad Through Military coercion and Intervention on Ground of Humanity, 1985, p. 26 e ss.

45 Louis Henkins defende essa possibilidade exemplificando o envio de aviões pelo Presidente Kennedy para salvar civis no Congo segundo sua autoridade para proteger americanos no exterior. Louis Henkins, Foreign Affairs and the Constitution, p.54. O poder de usar a força para proteger nacionais no exterior também foi reconhecido. In Re Neagle, 135 U.S.1(1890). O direito de proteção no exterior é tido como um dos privilégios e imunidades dos nacionais, US Slaughter-House Cases, 16 Wall 36,79 (US 1872). Somando-se a isso em 1948 os EUA adotaram uma legislação nacional estabelecendo o direito de fazer uso da força no exterior para proteger a vida e a propriedade dos norte-americanos no exterior contra a violência arbitrária. Art. 614 das Regulações da Marinha dos EUA mencionado por Antonio Cassese, International Law in a Divided World, 1986, p. 238. É importante observar que a decretação dessa legislação seguiu a adoção da Carta das Nações Unidas. Isso significa que os EUA consideram que em alguns casos como os de proteção dos nacionais no exterior, o uso da força é lícito.

Revista de Direito Internacional do Programa de Pós-Graduação em Direito da UERJ 


\section{AQUISIÇÃO DA NACIONALIDADE}

A nacionalidade adquirida no nascimento é denominada originária e baseia-se normalmente no ius solis - critério pelo qual o indivíduo adquire a nacionalidade do país de nascimento - ou no ius sanguinis - quando o indivíduo adquire a nacionalidade de seus genitores, não importando o local de nascimento ${ }^{46}$. Em qualquer um desses casos, o indivíduo receberá a condição de nacional nato. Já a aquisição posterior de nacionalidade ocorre normalmente através do processo da naturalização, quando, preenchidos certos requisitos legais, dá-se a concessão da nacionalidade derivada.

A nacionalidade brasileira pode ser adquirida no momento do nascimento - nacionalidade originária - ou posteriormente - nacionalidade derivada, via naturalização, ou seja com manifestação de vontade nesse sentido. O Brasil jamais admitiu a aquisição automática de outra nacionalidade em função do casamento47, o que era comum em alguns países e hoje já inadmitido pelo direito convencional 48 .

A aquisição da nacionalidade originária, isto é, aquela adquirida no momento do nascimento, é matéria formal e materialmente constitucional, já que se trata de definir um dos elementos do Estado. Nessa linha, todas as Constituições brasileiras trataram em sede constitucional da aquisição da

\footnotetext{
${ }^{46}$ Atualmente os países tendem a adotar uma mistura dos dois sistemas ou uma versão atenuada dos dois conceitos. A razão para isso é a necessidade e o desejo de evitar casos de apatrídia. Sobre os sistemas, V. Rezek, Le droit international de la nationalité, Recueil des Cours, 1986, p. 358 (ius solis) e 360 (ius sanguinis).

47 Ilmar Penna Marinho, Tratado sobre a Nacionalidade: do direito brasileiro da nacionalidade, 1957, pp. 316, 317 e 319. "Tal situação seria, aliás, hoje, a de muitas brasileiras casadas com italianos, alemães e japoneses se a nossa legislação não houvesse determinado sàbiamente que a mulher brasileira, casada com estrangeiro, conserva a sua nacionalidade (...).Efetivamente, à mulher, tal como ao homem, não pode ser imposta uma nacionalidade que não quer ou em relação à qual não se pode manifestar livre e expressamente. A evolução contemporânea do Direito Internacional repele a fórmula da escola clássica consistente em submeter a mulher a um dilema, torturado pela ideia da legalidade: ou se casa e se torna estrangeira, ou conserva a sua nacionalidade mas não se casa. Na concepção moderna, a mulher não deve receber uma nacionalidade imposta e o fato de escolher um marido não deve implicar o de escolher um novo estatuto. Eis porque o sistema da nacionalidade independente da mulher parece superior, já do ponto de vista moral ou filosófico, já do aspecto objetivo e prático. Enquanto do ponto de vista filosófico é o sistema mais condizente com as conquistas da democracia e dos direitos do homem, do aspecto objetivo e prático e aquele que mais liberdade dá à mulher para agir consoante o seu interesse, visto como embora conservando a sua nacionalidade,tem ela sempre diante diante de si a possibilidade de adquirir voluntariamente a nacionalidade do marido."

$4^{8}$ V. art. 8 da Convenção concernente a certas questões relativas aos conflitos de leis sobre nacionalidade, Decreto ${ }^{\circ}$ 21.798, de 06.09.1932; Convenção da ONU sobre a nacionalidade da mulher casada, de 1957, Decreto ${ }^{\circ}$ 64.216, de 18.03.1969, Convenção da ONU sobre a eliminação de todas as formas de discriminação contra a mulher de 1979, Decreto $n^{0}$ 4.377, de 13.09.2002. V. também a Convenção Europeia sobre nacionalidade de 1997, art.4. 
nacionalidade brasileira originária49. A nacionalidade derivada também sempre foi mencionada no texto das Constituições brasileiras ${ }^{50}$ sendo, porém, regulada e detalhada por lei ordinária.

A aquisição da nacionalidade brasileira originária é tratada no art. 12, I da Constituição em vigor:

Art. 12. São brasileiros:

I - natos:

a) os nascidos na República Federativa do Brasil, ainda que de pais estrangeiros, desde que estes não estejam a serviço de seu país;

b) os nascidos no estrangeiro, de pai brasileiro ou mãe brasileira, desde que qualquer deles esteja a serviço da República Federativa do Brasil;

c) os nascidos no estrangeiro de pai brasileiro ou de mãe brasileira, desde que sejam registrados em repartição brasileira competente ou venham a residir na República Federativa do Brasil e optem, em qualquer tempo, depois de atingida a maioridade, pela nacionalidade brasileira;

Assim, em conformidade com o texto constitucional, há quatro hipóteses de aquisição da nacionalidade originária. A primeira, prevista na alínea $a$, por força do princípio do ius solis que determina que a nacionalidade brasileira se adquire em virtude do nascimento ocorrido em território nacional. Assim, ainda que a criança tenha genitores estrangeiros, será brasileira nata.

É, porém, polêmica a situação da criança nascida no Brasil filha de estrangeiro a serviço de seu país. A respeito, discute-se a vigência do art. $2^{\circ}$ da Lei 818/1949 que prevê: "Quando um dos pais for estrangeiro, residente no Brasil a serviço de seu governo, e o outro for brasileiro, o filho, aqui nascido, poderá optar pela nacionalidade brasileira, na forma do art. 129, $n^{o}$ II, da Constituição Federal.” Nos termos do dispositivo, a criança aqui nascida só será brasileira nata após a opção.

A doutrina diverge quanto à solução para essa situação. O ponto de partida é a interpretação do referido dispositivo constitucional. A Constituição determina que a criança nascida no Brasil será brasileira nata, ainda que filha de estrangeiros, salvo se estes estiverem a serviço do seu país. Há duas interpretações possíveis: (1) quem nasce no Brasil será brasileiro, com exceção do

49 Art 6, I, II, III (1824), art. 69, $1^{\circ}, 2^{\circ}, 3^{\circ}$ (1891), art. 106,a, b (1934), art. 115 a, b (1937), art. 129, I, II (1946); art.140 I, a, b, c (1967), art. 145 I a, b, c (1969), art. 12 I, a, b, c (1988).

$5^{\circ}$ Art 6, IV, V (1824), art. $694^{\circ}, 5^{\circ}, 6^{\circ}$ (1891), art. 106 c, d (1934), art. 115 c, d (1937), art. 129 II, IV (1946); art.140 II, a, b (1967), art. 145 II a, b (1969), art. 12 II a, b (1988). 
filho de pai e mãe estrangeiros, ambos a serviço do seu país51; (2) a criança nascida no Brasil filha de pai ou mãe estrangeiro a serviço do seu país não será brasileira nata.

A primeira interpretação é a mais correta. Trata-se de interpretação mais favorável ao indivíduo, critério que deve ser adotado em matéria de atribuição de nacionalidade brasileira ${ }^{2}$. A se adotar outra interpretação, a criança aqui nascida pode ser estrangeira ou até mesmo apátrida, sem que essa seja a vontade expressa do legislador constituinte. Para essa corrente, o art. $2^{\circ}$ da Lei 818 será inconstitucional, pois se a criança já é brasileira nata pelo nascimento não há que se exigir a opção. Por outro lado, para aqueles que defendem a segunda interpretação, pode-se discutir a vigência do art. $2^{\circ}$ da Lei 818. Quanto a isso, também não há unanimidade e há três entendimentos possíveis.

Uma corrente entende que o dispositivo é inconstitucional, pois a lei ordinária não pode prever hipóteses de aquisição da nacionalidade originária53. Para esses, a criança é estrangeira, podendo se tornar brasileira somente pela naturalização. Outra corrente defende que o dispositivo é constitucional, por analogia à possibilidade de opção prevista na alínea $c^{54}$. Se o filho de brasileiro nascido no exterior pode fazer a opção, com muito mais razão poderia o filho de brasileiro aqui nascido, mesmo que também filho de estrangeiro a serviço de seu país. Uma terceira corrente sustenta que o dispositivo é inconstitucional com base em uma interpretação sistemática do art. 12. Como o legislador previu que a

${ }^{51}$ Vide Manual do Serviço Consular e Jurídico, edição 2010, Capítulo 5, Nacionalidade: "5.1.5 Quando um dos pais for estrangeiro e residir no Brasil a serviço de seu Governo e o outro for brasileiro, o filho nascido no Brasil será brasileiro, por força do artigo 12, I, "a", da Constituição." Frise-se que a referência à nacionalidade brasileira de um dos genitores é irrelevante, pois se o fundamento é o art. 12, I, a, o que importa é o local do nascimento e não a filiação.

${ }^{2}$ Note-se que o STF já adotou essa interpretação favorável à manutenção do vínculo: STF, j. 26.6.2003, QO no HC 83113, Rel. Min. Celso de Mello, RTJ 187/1069: “As hipóteses de outorga da nacionalidade brasileira, quer se trate de nacionalidade primária ou originária (da qual emana a condição de brasileiro nato), quer se cuide de nacionalidade secundária ou derivada (da qual resulta o "status" de brasileiro naturalizado), decorrem, exclusivamente, em função de sua natureza mesma, do texto constitucional, pois a questão da nacionalidade traduz matéria que se sujeita, unicamente, quanto à sua definição, ao poder soberano do Estado brasileiro. Doutrina. A perda da nacionalidade brasileira, por sua vez, somente pode ocorrer nas hipóteses taxativamente definidas na Constituição da República, não se revelando lícito, ao Estado brasileiro, seja mediante simples regramento legislativo, seja mediante tratados ou convenções internacionais, inovar nesse tema, quer para ampliar, quer para restringir, quer, ainda, para modificar os casos autorizadores da privação - sempre excepcional - da condição político-jurídica de nacional do Brasil. Doutrina".

53 Oscar Tenorio, Direito Internacional Privado, v. I, 1970, p.200.

54 Luís Roberto Barroso, Duas questões controvertidas sobre o direito brasileiro da nacionalidade. In: Jacob Dolinger. (Org.). A nova Constituição e o direito internacional, 1987, p. 52. 
criança nascida no exterior, filho de brasileiro ou brasileira a serviço do Brasil será brasileiro nato, não faz sentido tratar a hipótese inversa de forma diferente 55 . Assim, bastaria que um dos pais seja estrangeiro a serviço do seu país para que a criança não possa ser brasileira nata. Quanto a esse último argumento, apesar de sua lógica, há que se lembrar que os dispositivos sobre nacionalidade são unilaterais e a reciprocidade não é critério determinante para sua aquisição.

A segunda hipótese de aquisição da nacionalidade brasileira originária se baseia no critério do ius sanguinis conjugado com exercício de função no exterior e prevê que é brasileiro o filho de brasileira ou brasileiro que esteja representando o Brasil no exterior. Aqui, claramente o legislador constituinte adotou uma ótica extensiva para a atribuição da nacionalidade brasileira ao estabelecer que basta que o pai ou a mãe seja brasileiro a serviço do país para que a criança seja brasileira nata. A dúvida existente com relação a esse dispositivo diz respeito à natureza do serviço no exterior.

Questiona-se primeiramente se a hipótese inclui apenas trabalho a serviço da administração direta 56 - hipótese mais tradicional - ou se é extensiva também aos brasileiros a serviço da administração indireta57, tais como empresas públicas e sociedades de economia mista. Discute-se, ainda, se o trabalho deve ser permanente ou pode ser temporário. Aqui, mais uma vez, a melhor interpretação é aquela mais favorável à aquisição da nacionalidade brasileira. Diante da ausência de restrições no texto constitucional, não deve o intérprete criá-las. Portanto, a aquisição se dará ainda que o pai ou a mãe brasileiro esteja a serviço da administração indireta, bem como na hipótese de exercício de trabalho temporário na administração.

A terceira hipótese de aquisição da nacionalidade brasileira originária, também em virtude do ius sanguinis, determina a aquisição da nacionalidade brasileira para o filho de brasileira ou brasileiro, que não esteja a serviço da República Federativa do Brasil, registrado em repartição brasileira competente no exterior. Alguns esclarecimentos se fazem necessários sobre a hipótese.

55 Jacob Dolinger, Direito internacional privado - Parte geral, 2008, p. 168.

${ }^{6}$ Oscar Tenorio, Direito Internacional Privado, v. I, 1970.

57 Jacob Dolinger, Direito internacional privado - Parte geral, 2008, p. 169; José Afonso da Silva, Curso de direito constitucional positivo, 2009, p. 327, Alexandre de Moraes, Direito Constitucional, 2009, p. 209.

Revista de Direito Internacional do Programa de Pós-Graduação em Direito da UERJ 
Primeiramente, note-se que o legislador adotou o mesmo critério do dispositivo anterior: basta que um dos genitores seja brasileiro para que o filho possa ser registrado e adquira a nacionalidade brasileira. Além disso, a nacionalidade brasileira do genitor não precisa ser originária. O filho de genitor naturalizado pode se beneficiar desta possibilidade, desde que a naturalização seja anterior ao nascimento do filho no exterior. Isso porque a condição de brasileiro do pai ou da mãe deve existir à época do nascimento; de um lado, porque o texto constitucional assim o exige e, de outro, porque se trata de aquisição da nacionalidade originária, espécie que se baseia em situação existente à época do nascimento ${ }^{58}$.

Por fim, a repartição brasileira competente, como regra, é o consulado brasileiro da localidade em que se deu o nascimento. Note-se que o legislador constituinte utilizou a expressão "desde que sejam registrados em repartição brasileira competente", sem mencionar expressamente que o registro deve ter ocorrido no exterior. Todavia, não há lógica na interpretação pela qual se admite que o registro em questão possa ser realizado no Brasil. A hipótese trata do nascimento no exterior e do registro como condição para aquisição de nacionalidade brasileira, em exceção ao critério do ius solis. Neste ponto, há que se fazer interpretação histórica do dispositivo, decorrente do art. 140 da CF de 1967 e do art. 145 da CF de 1969, que sempre mencionaram expressamente o registro em repartição brasileira competente no exterior. Ademais, admitir a possibilidade de registro no Brasil tornaria sem sentido a segunda hipótese prevista na alínea $c$, que prevê para aqueles não registrados a necessidade de opção pela nacionalidade brasileira perante juiz federal59.

A quarta hipótese de aquisição da nacionalidade brasileira originária, também com base no critério do ius sanguinis, determina a aquisição do status de brasileiro nato para a criança que, filha de pai ou mãe brasileira, não tivesse

${ }^{58}$ Jacob Dolinger, Direito Internacional Privado - Parte geral, 2008, p. 180-1.

59 Em sentido contrário, V. TJRJ, DJ 03.setembro.2010, Ap. Civ. 0008393-60.2010.8.19.0000, Rel. Des. Ricardo Couto de Castro: "A tanto basta ver que o menor, já residindo aqui, através de sua representante, mais precisamente sua mãe, fez requerimento, no Cartório competente, optando pela nacionalidade brasileira. Por conseguinte, há que ser mantida a sentença, deferindose o pleito, sob pena do inusitado: impor-se viagem para o exterior, objetivando o registro junto ao Consulado do país onde a criança nasceu. Ora, diante do que se vê, induvidoso se torna interpretar a expressão “... desde que sejam registrados em repartição brasileira competente...”, de maneira ampla, a abranger, nos casos de retorno ao Brasil, também os Cartórios aqui competentes". 
sido registrada em repartição brasileira competente no exterior. Para estes, a Constituição estabelece a necessidade de opção, feita a qualquer tempo, no Brasil, perante juiz federal, nos termos da CF, art. 109, X. Para a opção, a Constituição exige que a criança tenha nascido no exterior, não tenha sido registrada na repartição brasileira competente, tenha pai ou mãe brasileiro, venha a residir no Brasil e que, após a maioridade, opte, perante o juiz federal pela nacionalidade brasileira ${ }^{60}$.

É importante frisar que, no Brasil, a opção sempre foi forma de manter a nacionalidade brasileira. No sistema anterior, em que deveria ser feita em até quatro anos após a maioridade, até então a criança poderia ter o registro provisório da nacionalidade brasileira, nos termos do art. 32 da Lei dos Registros Públicos (Lei nº 6.015/1973). Assim, a criança tinha a nacionalidade brasileira temporária até o término do prazo decadencial para a efetivação da opção. Tratava-se, portanto, de condição resolutiva. Se a opção fosse feita no prazo, a nacionalidade brasileira originária retroagia à data do nascimento, independentemente de ter sido ou não efetivado o registro temporário, que era feito somente por necessidades práticas. Caso não fosse realizada a opção no prazo estipulado pelo legislador constituinte, ainda que feito o registro provisório, a condição de brasileiro era cancelada de ofício. Atualmente, com a nova redação que foi dada ao dispositivo por força da EC 54/2007, questiona-se acerca da natureza da opção e do status daquele que ainda não optou e as conseqüências jurídicas no caso de não ser feita a opção.

Quanto à natureza da opção, parece ser orientação da doutrina e da jurisprudência classificá-la como condição suspensiva ${ }^{61}$. Assim, até que a opção

\footnotetext{
${ }^{60}$ Note-se que a opção só pode ser feita pelo próprio interessado: A opção pela nacionalidade, prevista no art. 12, I, c, da CF/88 (alterado pela ECR 3/94), tem caráter personalíssimo, somente podendo ser manifestada depois de alcançada a capacidade plena, não suprida pela representação dos pais. Assim, atingida a maioridade civil, enquanto não manifestada a opção, esta passa a constituir-se em condição suspensiva da nacionalidade brasileira. Essa foi a orientação adotada pela Turma para negar provimento a recurso extraordinário, em que se pretendia a concessão da nacionalidade brasileira a menores impúberes, sob a alegação de que o referido dispositivo constitucional não exige que o interessado atinja a maioridade para que possa exercitar a opção (CF/88: “Art 12. São brasileiros: I - natos:... c) os nascidos no estrangeiro, de pai brasileiro ou de mãe brasileira, desde que venham a residir na República Federativa do Brasil e optem, em qualquer tempo, pela nacionalidade brasileira;"). Precedente citado: AC 70 QO/RS (DJU de 8.10.2003). RE 418096/RS, rel. Min. Carlos Velloso, 22.3.2005. (RE-418096)

${ }^{61}$ STF, AC 70: "I. Nacionalidade brasileira de quem, nascido no estrangeiro, é filho de pai ou mãe brasileiros, que não estivesse a serviço do Brasil: evolução constitucional e situação vigente. 1. Na Constituição de 1946, até o termo final do prazo de opção - de quatro anos, contados da maioridade -, o indivíduo, na hipótese considerada, se considerava, para todos os efeitos, Revista de Direito Internacional do Programa de Pós-Graduação em Direito da UERJ 145
} 
seja feita o indivíduo é estrangeiro. Obviamente, se a opção jamais for feita, o indivíduo permanecerá com o status de estrangeiro. Nessa linha, não subsiste a possibilidade prevista no art. 32 da Lei dos Registros Públicos de registro provisório da nacionalidade brasileira. Como a opção pode ser feita a qualquer tempo, não faria sentido admitir-se o registro temporário, pois o indivíduo poderia ficar indefinidamente com esse status e a opção se tornaria desnecessária. Todavia, uma vez feita a opção, esta retroage à data do nascimento, produzindo efeitos ex tunc ${ }^{62}$, eis que se trata de hipótese de nacionalidade brasileira originária, ou seja, existente desde o nascimento. Assim, uma vez implementada a condição suspensiva (pela via da opção), o indivíduo passa a ser considerado brasileiro desde o seu nascimento. Há importantes conseqüências dessa conclusão, pois o filho ou filha desse indivíduo que tenha nascido no exterior, antes da opção do seu genitor, não poderá fazer a sua opção, pois será filho ou filha de estrangeiro. Porém, uma vez feita a opção pelo genitor, que é retroativa, a mesma oportunidade abre-se para o seu filho ou filha, que poderá comprovar o status de brasileiro do seu genitor à época do seu nascimento.

Por fim, há que se mencionar que a inovação trazida pela EC 54/2007, que reintroduziu no sistema constitucional brasileiro a terceira hipótese acima

brasileiro nato sob a condição resolutiva de que não optasse a tempo pela nacionalidade pátria. 2 . Sob a Constituição de 1988, que passou a admitir a opção "em qualquer tempo" - antes e depois da ECR 3/94, que suprimiu também a exigência de que a residência no País fosse fixada antes da maioridade, altera-se o status do indivíduo entre a maioridade e a opção: essa, a opção - liberada do termo final ao qual anteriormente subordinada -, deixa de ter a eficácia resolutiva que, antes, se lhe emprestava, para ganhar - desde que a maioridade a faça possível - a eficácia de condição suspensiva da nacionalidade brasileira, sem prejuízo - como é próprio das condições suspensivas -, de gerar efeitos ex tunc, uma vez realizada. 3. A opção pela nacionalidade, embora potestativa, não é de forma livre: há de fazer-se em juízo, em processo de jurisdição voluntária, que finda com a sentença que homologa a opção e lhe determina a transcrição, uma vez acertados os requisitos objetivos e subjetivos dela. 4. Antes que se complete o processo de opção, não há, pois, como considerá-lo brasileiro nato. II. Extradição e nacionalidade brasileira por opção pendente de homologação judicial: suspensão do processo extradicional e prisão domiciliar. 5. Pendente a nacionalidade brasileira do extraditando da homologação judicial ex tunc da opção já manifestada, suspende-se o processo extradicional (CPrCiv art. 265, IV, a). 6. Prisão domiciliar deferida, nas circunstâncias, em que se afigura densa a probabilidade de homologar-se a opção.” V. também STF, $D J$ 22.abril.2005, RE 418096/RS, Rel. Min. Carlos Velloso.

${ }^{62}$ Vide STF, AC 70, acima e TSE, j. 12.nov.2008, ED-ED-REspe n ${ }^{0}$ 29200/RS, Rel. Min. Eros Roberto Grau, RJTSE - Revista de jurisprudência do TSE, Volume 19, Tomo 4, Página 118, "Embargos de declaração. Embargos de declaração. Recurso Especial eleitoral. Omissão e contradição. Existência. Homologação de opção pela nacionalidade brasileira (artigo 12, inciso i, alínea "c", da CF). Efeitos ex tunc. Convalidação alistamento e filiação partidária. 1. O STF reconhece que a homologação, por sentença judicial, de opção pela nacionalidade brasileira (artigo 12, inciso I, alínea "c", da Constituição do Brasil) possui efeitos ex tunc. 2. A sentença homologatória da opção pela nacionalidade brasileira deve ser considerada fato novo suficiente para convalidar o alistamento eleitoral e a filiação partidária, em razão de seus efeitos retroativos, que são absolutos. (...)”. 
mencionada, trouxe algumas perplexidades. Em primeiro lugar, o registro em repartição brasileira competente passou a ser atributivo da nacionalidade brasileira originária, pois uma vez feito, nenhuma outra condição se lhe impõe. Além disso, não há prazo para o registro. Assim, ainda que feito muitos anos após o nascimento no exterior, seu efeito será o mesmo.

Por outro lado, a opção parece ter perdido sua razão de ser63. Após a maioridade e com a fixação da residência no país, a opção exige comparecimento perante juiz federal. Pergunta-se qual o sentido dessa opção se o registro consular pode ser feito a qualquer tempo? Ou seja, para aquele que vem fixar residência no Brasil, demonstrando um maior vínculo com o país, impõe-se um ônus maior, com a contratação de advogado e todas as dificuldades do processo judicial da opção; já para aquele que reside no exterior, basta que ele (ou seu genitor brasileiro) compareça perante o consulado brasileiro e requeira o registro. Não há qualquer razão que justifique tal incoerência.

Note-se que a opção deve ser feita perante juiz federal, como exigido pelo texto constitucional64. O juiz estadual é absolutamente incompetente para decidir questões atinentes à nacionalidade brasileira.

Pode-se também adquirir a nacionalidade brasileira derivada, pela naturalização. Prevê o texto constitucional:

Art. 12. São brasileiros

II - naturalizados:

a) os que, na forma da lei, adquiram a nacionalidade brasileira, exigidas aos originários de países de língua portuguesa apenas residência por um ano ininterrupto e idoneidade moral;

b) os estrangeiros de qualquer nacionalidade, residentes na República Federativa do Brasil há mais de quinze anos ininterruptos $e$ sem condenação penal, desde que requeiram a nacionalidade brasileira.

Portanto, são duas hipóteses de aquisição derivada da nacionalidade brasileira: (1) ordinária e (2) extraordinária. No primeiro caso, aplica-se a Lei no 6815/80 quanto aos requisitos e procedimento, ressaltando-se que o Ministro da

63 V. críticas feitas por Jacob Dolinger, Direito Internacional Privado - Parte Geral, 2008, p.1716.

${ }^{64} \mathrm{CF} / 88$ : "Art. 109. Aos juízes federais compete processar e julgar: (...)X - os crimes de ingresso ou permanência irregular de estrangeiro, a execução de carta rogatória, após o "exequatur", e de sentença estrangeira, após a homologação, as causas referentes à nacionalidade, inclusive a respectiva opção, e à naturalização".

Revista de Direito Internacional do Programa de Pós-Graduação em Direito da UERJ 
Justiça ${ }^{65}$ pode negar o pedido ainda que preenchidos todos os requisitos legais, pois se trata de poder discricionário do Executivo; já no segundo caso, presentes os requisitos previstos no texto constitucional - residência no Brasil há mais de quinze anos ininterruptos e inexistência de condenação penal no Brasil ou no exterior - a naturalização deve ser obrigatoriamente concedida.

\section{PERDA E REAQUISIÇÃO DA NACIONALIDADE}

Todas as Constituições brasileiras possuíram dispositivos sobre a perda da nacionalidade 66 . Há algumas hipóteses presentes ao longo de toda a história constitucional brasileira, ao passo que outras deixaram de existir mais recentemente. É o caso da regra de que perde a nacionalidade brasileira aquele que, sem licença, exerce emprego ou recebe pensão de governo estrangeiro, em vigor desde a Constituição Imperial até a Constituição de 1969. A hipótese presente em todas as constituições prevê a perda da nacionalidade brasileira para aquele que se naturaliza estrangeiro. Alguns pontos devem ser ressaltados quanto a essa situação.

O legislador constituinte sempre exigiu que a nacionalidade estrangeira fosse adquirida por naturalização, ou seja, a nacionalidade estrangeira adquirida deve ser derivada, posterior ao nascimento. A aquisição por força de situações existentes à época do nascimento não acarreta a perda da nacionalidade brasileira ${ }^{67}$. Assim, aquisições de nacionalidades estrangeiras por força do ius sanguinis (pai ou mãe estrangeiro) não afeta a nacionalidade brasileira.

Ademais, a naturalização há que ser voluntária, ou seja, decorrer da vontade do adquirente. Veja-se que, por naturalização voluntária entende-se aquela que decorre inequivocamente da manifestação de vontade do adquirente, não se podendo entender que o silêncio da parte possa ser definido como tal68. A

${ }^{6}$ L 6.815/80: "Art. 111. A concessão da naturalização nos casos previstos no artigo 145, item II, alínea b, da Constituição, é faculdade exclusiva do Poder Executivo e far-se-á mediante portaria do Ministro da Justiça".

66 Artigo $7^{\circ}$, na Constituição de 1824; artigo 71, na Constituição de 1891; artigo 107, na Constituição de1934; artigo 116, na Constituição de1937; artigo 130, na Constituição de 1946; artigo 141, na Constituição de 1967; artigo 146, na Constituição de 1969 e artigo $12 \S 4^{\circ}$, da Constituição de 1988.

${ }_{67}$ Trata-se, vale dizer, de interpretação coerente com os dispositivos constitucionais das constituições anteriores e alinhada com o espírito do legislador da Emenda Constitucional $\mathrm{n}^{\mathrm{o}}$. 3/1994, cujo objetivo era reduzir as hipóteses de perda da nacionalidade brasileira.

68 Jacob Dolinger, Direito Internacional Privado - Parte Geral, 2008, p. 188. Para perder a nacionalidade brasileira mediante aquisição de outra, esta terá de ser voluntariamente adquirida, ou seja, mediante manifestação expressa do naturalizado. Uma aquisição imposta ou uma 148

Cosmopolitan Law Journal, v. 2, n. 1, jun. 2014, p. 131-167 
jurisprudência, aliás, já perfilhou esse mesmo entendimento, de que para fins de perda da nacionalidade brasileira, a naturalização deveria resultar de manifestação de vontade clara neste sentido. Assim, a simples omissão ou silêncio não poderia ser caracterizada como tal ${ }^{69}$.

A Emenda $n^{0}$ 3/94 evidenciou ainda mais tal circunstância, determinando que mesmo na hipótese de naturalização em país estrangeiro o brasileiro manterá a sua nacionalidade caso a aquisição tenha decorrido de circunstâncias que o compeliram a adquirir a nacionalidade estrangeira. Ou seja, a naturalização foi necessária para que o indivíduo permanecesse no país ou para que exercesse direitos civis. Tratar-se-ia, por exemplo, de naturalização para exercício de profissão, aquisição de imóvel ou situação similar. Essa verificação se dará casoa-caso, sempre se adotando interpretação mais favorável à manutenção da nacionalidade brasileira70. A perda, vale dizer, é declaratória, retroagindo à data da aquisição da nacionalidade estrangeira.

aceitação tácita de nacionalidade estrangeira não rompe os laços com a nacionalidade brasileira. Por exemplo, a legislação de Israel prescreve a aquisição automática da nacionalidade israelense no momento da obtenção do status de imigrante por pessoa de religião judaica, como regulado na "Lei de Retorno", combinada com a "Lei de Nacionalidade." No mesmo sentido, Ilmar Penna Marinho, Tratado sobre a Nacionalidade: do direito brasileiro da nacionalidade, 1957, p. 757. ${ }^{69}$ STF, DJU 05 set. 1975, SE 2260, Rel. Min. Leitão de Abreu. No mesmo sentido, vide decisão de 25 jul. 1957, do Supremo Tribunal Federal, citada por Ilmar Penna Marinho: “(...) nos casos de aquisição de outra nacionalidade, a perda da qualidade de brasileiro só se dará quando o brasileiro tiver feito expressa manifestação de vontade. (Pedido de segurança de Ana Adelina Caitchik contra ato do Governo que lhe cassara a nacionalidade brasileira sob fundamento de haver ela adquirido tàcitamente a israelense em virtude de simples permanência no território de Israel e consoante dispositivo de lei desse país)." [Ilmar Penna Marinho, Tratado sobre a Nacionalidade: do direito brasileiro da nacionalidade, 1957, p. 757].

$7^{70}$ Vale citar trecho do MJ em matéria de perda da nacionalidade brasileira:

"A competência do Departamento de Estrangeiros da Secretaria Nacional de Justiça do Ministério da Justiça, mais se acentua em relação à situação jurídica do estrangeiro no Brasil e não à de brasileiros no exterior.

Verifica-se a exceção em relação à perda da cidadania brasileira, originária ou derivada, quando ocorre opção por outra nacionalidade, nos termos do que dispõe $\S 4^{\circ}$ do artigo 12 da Constituição Federal de 1988, com redação dada pela Emenda Constitucional de revisão no o3/94:

" $\$ 4^{\circ}$ Será declarada a perda da nacionalidade do brasileiro que:

I. tiver cancelada a sua naturalização, por sentença judicial, em virtude de atividade nociva ao interesse nacional;

II. adquirir outra nacionalidade, salvo nos casos:

a) de reconhecimento de nacionalidade originária pela lei estrangeira;

b) de imposição de naturalização, pela norma estrangeira, ao brasileiro residente em Estado estrangeiro, como condição para permanência em seu território ou para o exercício de direitos civis."

A única condição de perda da nacionalidade brasileira é a demonstração do desejo expresso e inequívoco de perdê-la e de mudar de nacionalidade." Disponível em: $<$ www.mj.gov.br>.

Revista de Direito Internacional do Programa de Pós-Graduação em Direito da UERJ 
A hipótese de perda por exercício de atividade nociva ao interesse nacional também esteve presente em todas as Cartas com exceção da Constituição Republicana e aplica-se somente ao naturalizado ${ }^{71}$, exigindo-se sentença judicial para esse cancelamento. A decisão judicial compete ao juiz federal e produzirá efeitos ex nunc.

Quanto à reaquisição da nacionalidade, prevista na Lei no 818/49, exigese que o requerente esteja domiciliado no Brasil e solicite ao Presidente da República72 a revogação do seu decreto de perda da nacionalidade brasileira. Discute a doutrina se a reaquisição é uma naturalização específica para exbrasileiros ou se permite que se retorne ao status anterior (nato ou naturalizado). $\mathrm{Na}$ primeira hipótese, o brasileiro nato que perde a nacionalidade, pela reaquisição, passará a ser naturalizado. Para a segunda corrente, que parece ser a melhor por ser mais benéfica ao indivíduo envolvido, o brasileiro nato que deixa de ser brasileiro readquire o seu status de nato73.

\section{DISTINÇÕES ENTRE NACIONAIS}

A distinção entre tipos de nacionalidade é prática bastante disseminada, a despeito de ser, via de regra, discriminatória. A razão da distinção remonta à discriminação em relação aos estrangeiros. Pode-se dizer que a pessoa naturalizada é um ex-estrangeiro; desta forma tem-se a ideia de que este indivíduo, pela sua origem alienígena, nunca será digno de confiança absoluta74.

Tanto no caso de nacionalidade originária como no caso de naturalização, o indivíduo receberá o status de nacional de determinado Estado. A maior parte

\footnotetext{
${ }^{71}$ Note-se que a Carta da 1824 previa a hipótese de perda punição para o nato e o naturalizado, indistintamente.

${ }^{72}$ L 818/49: "Art. 36 - O brasileiro que, por qualquer das causas do art. 22, números I e II, desta lei, houver perdido a nacionalidade, poderá readquiri-la por decreto, se estiver domiciliado no Brasil. $\S 1^{\mathrm{O}} \mathrm{O}$ pedido de reaquisição, dirigido a Presidente da República, será processado no Ministério da Justiça e Negócios Interiores, ao qual será encaminhado por intermédio dos respectivos Governadores, se o requerente residir nos Estados ou Territórios".

73 Sobre as duas correntes, V. Nadia de Araújo, Perda e Reaquisição da Nacionalidade Brasileira. In: Jacob Dolinger (coord.), A Nova Constituição e o Direito Internacional, p. 55 e ss..

74 A Suprema Corte norte-americana no caso Schneider $x$ Rusk (377 US 163-1964) invalidou o requerimento de residência aplicado aos naturalizados, mas não aos nativos segundo o argumento que não era permissível a presunção que os naturalizados eram uma classe menos confiável e que teriam menos lealdade que os nativos. No entanto, apesar desta manifestação da Suprema Corte a Constituição norte-americana proíbe que algumas funções sejam exercidas por naturalizados, tais como a Presidência e a Vice-presidência do país (artigo II da Emenda XII) e também estabelece que os naturalizados têm que esperar alguns anos após a naturalização para poderem ser Senadores (9 anos - artigo I, seção 3, parágrafo 3) e deputados (7 anos - artigo I, seção 2 parágrafo 2 ). 
dos países, no entanto, estabelece uma diferença fundamental entre essas categorias de nacionais. O nacional originário goza de todos os direitos inerentes à condição de nacional, enquanto o naturalizado desfruta de status inferior, porquanto não usufrui os mesmos direitos e benefícios assegurados aos primeiros.

No Brasil, a Constituição Republicana de 1891 apenas negava o acesso a Presidência e Vice-presidência aos brasileiros naturalizados, exatamente como a Constituição dos EUA. O alcance da discriminação contra os naturalizados cresceu vertiginosamente até a Constituição de 1969 que criou 22 diferentes tipos de discriminação contra o naturalizado75. A Constituição de 1988 reduziu os tipos de discriminação restringindo-os às seguintes funções que não podem ser exercidas por brasileiros naturalizados: (1) Presidente, Vice-presidente ou Presidente da Câmara dos Deputados ou do Senado; (2) ministro do Supremo Tribunal Federal; (3) membro da carreira diplomática ou oficial das Forças Armadas (art. 12, §3); (4) membro do Conselho da República (art. 89, VII). Ademais, brasileiros naturalizados (5) não podem ser proprietários, administradores ou diretores de empresa jornalística antes de dez anos depois da naturalização (art. 222); (6) podem perder a nacionalidade brasileira por atividade nociva ao interesse nacional e (7) podem ser extraditados por crimes relacionados com tráfico de drogas ou crimes comuns cometidos antes da aquisição da nacionalidade brasileira. Neste último caso - crime comum cometido antes da naturalização - a naturalização será nula, pois decorrente de declaração falsa, não se tratando, a rigor, de extradição de naturalizado.

Em geral, a Constituição em vigor equipara os brasileiros naturalizados aos natos, salvo as exceções previstas no próprio texto constitucional 76 , acima descritas. Isso significa que a lei ordinária não pode criar distinções não contempladas pela Constituição, sendo inconstitucionais as leis nesse sentido.

\section{POLIPATRÍdia E APATRÍdia}

Como resultado da discricionariedade dos Estados relativamente à formulação de leis sobre nacionalidade, dois ou mais países podem, ao mesmo

75 Ver Jacob Dolinger, Os Brasileiros Naturalizados no Poder Público. In: Jacob Dolinger (org.), A Nova Constituição e o Direito Internacional.

${ }^{76}$ Art. $12 \S 2^{0}$ - A lei não poderá estabelecer distinção entre brasileiros natos e naturalizados, salvo nos casos previstos nesta Constituição.

Revista de Direito Internacional do Programa de Pós-Graduação em Direito da UERJ 
tempo, reconhecer determinado indivíduo como seu nacional. Veja-se, por exemplo, o caso de uma criança nascida em determinado Estado que adote a regra do ius solis, cujos genitores são nacionais de outro Estado, que aplique a regra do ius sanguinis. A criança terá duas nacionalidades ao nascer: uma do Estado nascimento, e outra do Estado da nacionalidade de seus pais. A dupla nacionalidade pode também ocorrer quando um indivíduo nacional de certo Estado adquire nacionalidade derivada, pela naturalização, e não perde a nacionalidade anterior. Além desses casos mais comuns, a polipatrídia pode igualmente surgir quando há uma cessão parcial ou total de certo território à soberania de outro Estado, e os residentes deste território adquirem a nacionalidade do novo soberano, sem, contudo, perder a antiga 77.

Em matéria de polipatrídia, vigorava anteriormente o princípio de que a nacionalidade tinha que ser una. Ou seja, ainda que o indivíduo fosse binacional, ele seria considerado como tendo somente uma das nacionalidades em questão. Nessa linha, a Comissão de Direito Internacional da ONU, em 1954, estabeleceu a seguinte regra: "Toda pessoa tem o direito a uma nacionalidade - mas somente a uma"78. Essa tendência está sendo revista. Exemplo disso é a Convenção Europeia sobre Nacionalidade, de 1997 que admite a dupla nacionalidade em alguns casos79.

O tema é questão mais afeta ao direito internacional do que ao direito interno, embora poucos diplomas convencionais tratem do assunto e, quando o fazem, pequem pela omissão. É o caso do Protocolo da Haia Relativo às Obrigações Militares em Certos Casos de Dupla Nacionalidade, que, como o próprio nome da convenção indica, apenas trata do efeito da dupla nacionalidade em relação ao serviço militar ${ }^{80}$. Havendo mais de uma nacionalidade, cada um

\footnotetext{
77 Ver Nissim Bar-Yaacov, Dual Nationality, 1961, p. 3-4.

${ }^{78}$ Institut de Droit International, Tableau Général des Résolutions (1873-1956), 1957, p. 41.

79 Arts. 14 a 17.

80 Promulgado pelo Decreto $\mathrm{n}^{0}$ 21.798/32.

152

Cosmopolitan Law Journal, v. 2, n. 1, jun. 2014, p. 131-167
} 
dos Estados envolvidos irá reconhecer apenas a sua própria nacionalidade ${ }^{81}$. Em face de um terceiro Estado, considerar-se-á a nacionalidade mais efetiva ${ }^{82}$.

Sobre o tema, vale lembrar o famoso Caso Nottebohm, decidido pela Corte Internacional de Justiça da Haia. Friedrich Wilhelm Nottebohm, nacional alemão e que residia e tinha negócios na Guatemala, em 1939, no início da Segunda Guerra Mundial, adquiriu a nacionalidade derivada de Liechtenstein (naturalização). Todavia, continuou domiciliado na Guatemala. Em 1943, foi preso e deportado para os EUA, como nacional de país inimigo (Alemanha), e, em 1949, teve os seus bens confiscados na Guatemala, para onde foi impedido de voltar. Por essa razão, Nottebohm fixou domicílio em Liechtenstein, que submeteu à Corte Internacional de Justiça da Haia pedido indenizatório pela sua prisão e deportação e pela expropriação de seus bens. A Corte proferiu decisão histórica na qual não considerou Liechtenstein parte legítima para representar Nottebohm, já que a nacionalidade desse país não fora adquirida em conformidade com os parâmetros estabelecidos pelo Direito Internacional (não havia laços fáticos fortes entre a pessoa e o Estado no momento da aquisição da nacionalidade). Portanto, aplicou a Corte a regra da nacionalidade prevalente ou nacionalidade real e efetiva ${ }^{8}$.

Em matéria extradicional, o STF debateu se o critério da nacionalidade efetiva poderia ser utilizado no caso de dupla nacionalidade, em que uma das

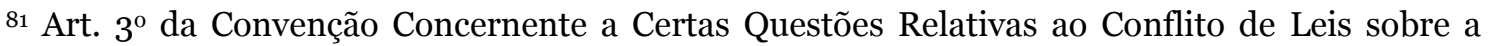
Nacionalidade (Haia -1930): "Sob reserva das disposições da presente Convenção, um indivíduo que tenha duas ou mais nacionalidades poderá ser considerado por cada um dos Estados cuja nacionalidade possua, como seu nacional; art. $9^{\circ}$ do Código de Bustamante (Havana -1928) estabelece que: "Cada Estado contratante aplicará o seu direito próprio à determinação da nacionalidade de origem de toda pessoa individual ou jurídica e à sua aquisição, perda ou recuperação posterior, realizadas dentro ou fora do seu território, quando uma das nacionalidades sujeitas à controvérsia seja a do dito Estado...”

82 Art. 10 do Código de Bustamante determina: "Às questões sobre nacionalidade de origem em que não esteja interessado o Estado em que elas se debatem, aplicar-se-á a lei daquela das nacionalidades discutidas em que tiver domicílio a pessoa que se trate" e o Art. 5 da Convenção de Haia sobre Nacionalidade estabelece: "Em um terceiro Estado, o indivíduo que possua várias nacionalidades deverá ser tratado como se não tivesse senão uma. Sem prejuízo das regras de direito aplicadas no terceiro Estado em matéria de estatuto pessoal e sob reserva das convenções em vigor, esse Estado poderá, em seu território, reconhecer exclusivamente, entre as nacionalidades que tal indivíduo possua, tanto a nacionalidade do país no qual ele tenha residência habitual e principal, quanto a nacionalidade do país, ao qual, segundo as circunstâncias, ele, de fato, pareça mais ligado.”

83 V. crítica de Jacob Dolinger à decisão em Jacob Dolinger, Nottebohm revisited. In: Paulo Borba Casella (org.), Dimensão internacional do direito- estudos em homenagem a G.E. do Nascimento e Silva.

Revista de Direito Internacional do Programa de Pós-Graduação em Direito da UERJ 
nacionalidades em questão era a brasileira, concluindo pela afirmativa ${ }^{84}$. Como o devido respeito, observa-se que o princípio da nacionalidade efetiva não é aplicável à hipótese: de lege lata, sua aplicação ocorre somente nos casos de dupla nacionalidade julgados por um terceiro Estado. Isto é o que dispõe o Código Bustamante, art. 10 85 , e também a Convenção da Haia Concernente a Certas Questões Relativas ao Conflito de Leis sobre a Nacionalidade e Três Protocolos, art. $5^{\text {o86 }}$, já transcritos, ambos ratificados pelo Brasil.

Na hipótese decidida pelo STF, como uma das nacionalidades é a brasileira e a questão é discutida no Brasil, determinam os suprarreferidos Tratados, respectivamente nos arts. $9^{\circ}$ e $3^{\circ}$, que o Brasil deverá levar em conta a nacionalidade brasileira do indivíduo. A nacionalidade estrangeira não tem qualquer relevância no plano interno, de acordo com a regra tradicional do Direito Internacional de que "todo indivíduo deve ter uma nacionalidade, e não mais do que uma"87. O portador de dupla nacionalidade não perderá a estrangeira, mas somente porque o Estado brasileiro não interfere em assuntos afeitos à soberania dos outros países como o é a nacionalidade.

Além disso, conforme mostra Daniela Vargas, ${ }^{88}$ o ordenamento jurídico brasileiro observa sempre a nacionalidade do indivíduo pelo prisma da brasilidade. Pergunta-se: “é brasileiro ou não é?”. A posição fica patente quando se estuda o requisito da opção pela nacionalidade brasileira, presente também no art.12, I, c da Constituição.

Nessa linha, o STF, em caso de dupla nacionalidade, privilegiou a nacionalidade brasileira:

${ }^{84}$ STF, DJ 04.março.2005, HC n. ${ }^{\circ} 83.450-7 /$ SP, Rel. Min. Marco Aurélio, Rel. p/ac. Min. Nelson Jobim, p. 11: "Habeas corpus. Informações de provável pedido de extradição. Dupla nacionalidade. Proibição de extradição de nacional. Não há nos autos qualquer informação mais aprofundada ou indícios concretos de suposto processo em tramitação na Justiça da Itália que viabilizaria pedido de extradição. O processo remete ao complexo problema da extradição no caso da dupla-nacionalidade, questão examinada pela Corte Internacional de Justiça no célebre caso Nottebohm. Naquele caso a Corte sustentou que na hipótese de dupla nacionalidade haveria uma prevalecente - a nacionalidade real e efetiva - identificada a partir de laços fáticos fortes entre a pessoa e o Estado. A falta de elementos concretos no presente processo inviabiliza qualquer solução sob esse enfoque. Habeas corpus não conhecido."

85 Convenção de Direito Internacional Privado de 1928 (Código Bustamante), Decreto ${ }^{\circ} .18 .871$ de 13.08.1929.

${ }^{86}$ Decreto $\mathrm{n}^{\circ} .21 .798$ de 06.09.1932 que internalizou a Convenção da Haia de 1930.

87 Celso R. D. de Albuquerque Mello, Curso de Direito Internacional Público, vol. II, 2004.

88 Daniela Trejos Vargas, Atribuição da Nacionalidade Brasileira pelo critério do ius sanguinis ao filho de brasileiro nascido no exterior, à luz das modificações introduzidas pela Emenda Constitucional de Revisão $n^{\circ} .3$ de 1994. Rio de Janeiro, PUC, 1997. 
O brasileiro nato, quaisquer que sejam as circunstâncias e a natureza do delito, não pode ser extraditado, pelo Brasil, a pedido de Governo estrangeiro, pois a Constituição da República, em cláusula que não comporta exceção, impede, em caráter absoluto, a efetivação da entrega extradicional daquele que é titular, seja pelo critério do jus soli, seja pelo critério do jus sanguinis, de nacionalidade brasileira primária ou originária. Esse privilégio constitucional, que beneficia, sem exceção, o brasileiro nato (CF, art. $\left.5^{\circ}, L I\right)$, não se descaracteriza pelo fato de o Estado estrangeiro, por lei própria, haver-lhe reconhecido a condição de titular de nacionalidade originária pertinente a esse mesmo Estado $\left(\mathrm{CF} \text {, art. } 12, \S 4^{o}, I I, a\right)^{89}$.

O outro lado da moeda, também decorrente da discricionariedade dos Estados em matéria de atribuição de nacionalidade, é o fenômeno da apatrídia, que ocorre quando um indivíduo que não é considerado nacional pelas leis de nenhum Estado90.

A apatrídia pode decorrer das seguintes situações: (1) renúncia voluntária da nacionalidade, quando tal renúncia é admitida; (2) conflito das leis de nacionalidade, isto é, uma criança nascida num país que adote as regras do ius sanguinis, cujos pais são de um país que adota a regra do ius soli; (3) mudanças territoriais e inadequação dos tratados sobre povoamento; (4) perda de nacionalidade, isto é, quando um Estado, em conformidade com suas próprias leis, priva o indivíduo de sua nacionalidade 91.

Há algumas convenções em vigor que objetivam evitar a apatrídia. Merecem destaque, neste ponto, a Convenção de 1961 para Reduzir os Casos de Apatridia e a Convenção da Haia de 1930 sobre Determinadas Questões Relativas aos Conflitos de Leis sobre a Nacionalidade e seus Protocolos. Os dois instrumentos, ainda que em contextos distintos, têm por objetivo reduzir as hipóteses de conflito negativo de leis em matéria de nacionalidade. Em relação à condição jurídica dos apátridas, é necessário mencionar a Convenção de 1954 sobre o Estatuto dos Apátridas.

\section{COMPETÊNCIA PARA ATRIBUIR A NACIONALIDADE}

\footnotetext{
${ }^{89}$ STF, DJ 29.agosto.2003, Questão de Ordem no HC no 83.113, Rel. Min. Celso de Mello. 90 Convenção sobre o Estatuto dos Apátridas: "Art. 1 (1) Para os efeitos da presente Convenção, o termo "apátrida" designará toda pessoa que não seja considerada seu nacional por nenhum Estado, conforme sua legislação".

${ }^{91}$ A. Peter Mutharika, The Regulation of Statelessness under International and National Law, Text and Documents, 1977.

Revista de Direito Internacional do Programa de Pós-Graduação em Direito da UERJ 
Pode parecer paradoxal atentar para os princípios internacionais concernentes à nacionalidade, dado que a determinação da nacionalidade do indivíduo é sempre estabelecida pelo direito interno, por ser consequência direta da soberania estatal. Costuma-se afirmar que as questões relativas à nacionalidade competem à jurisdição doméstica do Estado envolvido: "Nationality of an individual is his quality of being a subject of a certain state, and therefore its citizen. It is not for international law but for municipal law to determine who is, and who is not, to be considered a subject" 92.

É interessante observar que se por um lado a determinação da nacionalidade, bem como os direitos e deveres dela decorrentes dependem das leis internas do Estado em questão, o termo nacionalidade, no entanto, expressa um conceito de direto internacional. A coexistência dos Estados e a existência de relações internacionais constituem, ao menos atualmente, pré-requisitos do conceito de nacionalidade. Os nacionais são protegidos pelo Estado de origem quando no exterior, e, internamente, os Estados respeitam os nacionais de outros países. Acrescente-se ainda que ao determinar seus nacionais, os Estados indiretamente definem quem não goza daquela condição93.

Consequentemente, não é somente uma questão doméstica, mas também internacional. Por essa razão, o direito do Estado para decidir problemas relativos à nacionalidade pode, também, ser delimitado por convenções e costumes internacionais, e pelos princípios gerais de direito reconhecidos 94 . Não há muita discussão quanto à existência de regras consuetudinárias de direito internacional limitando a liberdade dos Estados para determinar quem são os seus nacionais.

\footnotetext{
92 Oppenheim, International Law, v. I, p. 642 (8th ed. 1955). CIJ, Caso Nottebohm (ICJ Reports 1955, 4, 20-21): "It is for Liechtenstein, as it is for every sovereign State, to settle by its own legislation the rules relating to the acquisition of its nationality, and to confer that nationality by naturalization granted by its own organs in accordance with that legislation". Convenção concernente a certas Questões relativas ao Conflito de Leis sobre a Nacionalidade (Haia, 1930) (Decreto n. ${ }^{\circ}$ 21.798/32), Art. $1^{\circ}$, primeira parte: "Cabe a cada Estado determinar por sua legislação quais são os seus nacionais". Art. $2^{\circ}$ : "Toda questão relativa ao ponto de saber se um indivíduo possui a nacionalidade de um Estado será resolvida de acordo com a legislação desse Estado". Art. $3^{\circ}$ da Convenção Europeia sobre Nacionalidade (Conselho da Europa, 1997).

93 Ver Prof. Scelle, Precis de Droit des Gens, pag. 66: "Determiner la nationalité des individus c'est, non seulement determiner quels sont les nationaux, mais aussi quels sont les non-nationaux ou les étrangers. C'est donc indirectement fixer le statut international des non-nationaux et, par consequent, la compétence à l'egard des sujets de droit de la communauté internationale des autorités gouvernamentales étrangères."

94 Convenção de Haia sobre Nacionalidade, Art. 1.

156

Cosmopolitan Law Journal, v. 2, n. 1, jun. 2014, p. 131-167
} 
O aspecto mais difícil do problema, no entanto, parece ser o exato conteúdo dessas regras 95 .

Essas regras de direito internacional consuetudinário referentes à nacionalidade são divididas em: (a) regras positivas ${ }^{96}$ impondo uma obrigação internacional em certos casos; (b) regras negativas ${ }^{97}$, que impedem a aceitação de certas normas locais; e (c) regras de conflitos ${ }^{98}$, que determinam a nacionalidade prevalecente.

Zeballos, estudioso do assunto, estabeleceu, em 1914, algumas regras concernentes à nacionalidade que sempre teriam que ser respeitadas. Nomeou esses princípios "axiomas dos princípios da nacionalidade"99:

(1) a nacionalidade é um laço voluntário, "bona fide";

(2) é imperativo ao indivíduo possuir uma nacionalidade;

(3) não se há de cogitar de dupla nacionalidadeioo;

(4) é facultado ao indivíduo a livre mudança de sua nacionalidade ${ }^{101}$;

(5) como consectário do item 4, é vedado ao Estado impedir a mudança de nacionalidade;

(6) é vedado ao Estado compelir o indivíduo à involuntária mudança de nacionalidade ${ }^{102}$;

(7) é facultada ao indivíduo a recuperação da nacionalidade abandonada;

(8) é vedado ao Estado impor sua nacionalidade ao indivíduo domiciliado em seu território;

95 Chan, The Right to a Nationality as a Human Right, 12 Human Rights Law Journal 1-14 elabora uma lista das inúmeras regras de direito internacional em relação a nacionalidade visando principalmente evitar apatrídia.

${ }_{96}$ Weis concluiu no seu trabalho que não existe base no direito consuetudinário internacional para o direito ã nacionalidade. Paul Weis, Nationality and Statelessness in International Law (1956), p. 248. No entanto, contrariamente ao seu ponto de vista, o Protocolo de Haia Relativo a um Caso de Apatrídia e a Convenção da ONU sobre Redução da Apatrídia, Nova York, 1961 estabelecem no art. $1^{\circ}$ que um Estado deveria conceder sua nacionalidade para um indivíduo nascido no seu território que de outra forma tornaria se um apátrida. No mesmo sentido, o art. $6^{0}$ da Convenção Europeia sobre Nacionalidade (Conselho da Europa, 1997). Todavia, Weis está certo no que se refere à inefetividade dessas normas positivas.

97 Essas são as regras mais comumente encontradas e determinam que as leis locais, as quais concedem nacionalidade a um indivíduo não terão efeito extraterritorial se elas violarem o direito internacional. Um bom exemplo disto é a regra que estabelece a voluntariedade da naturalização. Isto é, naturalização contra a vontade do indivíduo não será reconhecida extraterritorialmente. V. Art. $3^{\circ}, 2$ da Convenção Europeia sobre Nacionalidade (Conselho da Europa, 1997).

98 Nos casos de dupla nacionalidade, por exemplo, em que o direito internacional concede prioridade para a nacionalidade mais efetiva.

99 Zeballos, La Nationalité, v. I, 1914, p. 233-5.

${ }^{100}$ Ele cita Cicero, Oratio pro Balbo: Duarum civitatum civis esse, nostro iure civile, nemo potest.

${ }^{101}$ Ele cita Platão, Sócrates, Cicero: Ne quis invitus in civitate maneat.

${ }^{102}$ Citando Cicero: Ne quis invitus civitate mutetur.

Revista de Direito Internacional do Programa de Pós-Graduação em Direito da UERJ 
(9) a nacionalidade original ou aquela que foi voluntariamente adquirida irá determinar a aplicabilidade do direito privado e público;

(10) todo Estado é obrigado a determinar o status do apátrida no direito público e privado ${ }^{103}$;

Lauterpacht propôs o direito à nacionalidade em razão do lugar do nascimento, a não privação da nacionalidade salvo se acompanhada pela aquisição de uma nova nacionalidade e o reconhecimento do direito de emigração e expatriação ${ }^{104}$.

Jacob Dolinger ${ }^{105}$ enfatiza o fato de que, dentro do conceito de nacionalidade, existem importantes sub-conceitos. A liberdade de aquisição derivada de nacionalidade é corolário dos direitos de mudar ou de não mudar determinada nacionalidade. $\mathrm{O}$ direito do indivíduo de mudar sua nacionalidade compreende os direitos de perder e de adquirir determinada nacionalidade. Encontram-se ainda compreendidos no direito de não perder determinada nacionalidade os direitos de não adquirir certa nacionalidade e de não perder a própria.

O direito do indivíduo perder certa nacionalidade é hoje reconhecido pela grande maioria dos países e também em inúmeros instrumentos de direito internacional106, pelo que a ideia de que "uma vez súdito sempre súdito" não mais se verifica atualio7.

\footnotetext{
${ }^{103}$ Algumas dessas regras tornaram-se, posteriormente, parte de instrumentos de proteção dos direitos humanos.

104 Lauterpacht, International Law and Human Rights, 1968, p. 346-50.

105 Jacob Dolinger, Direito International Privado - Parte geral, 2008, p. 199 e ss.

106 Art. XIX, American Declaration; art. 20, 3 da Convenção Americana; art. 15,2 da Declaração Universal .

107 V. Oppenheim, International Law, p. 393. Na primeira metade do século XIX, o Reino Unido ainda adotava o princípio do "nemo potest exuere patriam", mas o Naturalization Act de 1870 admitiu a perda da nacionalidade britânica por naturalização no exterior. O Nationality Act de 1948 foi mais longe, terminando com a idéia da unicidade da nacionalidade. Este ato permitiu a naturalização e definiu que a naturalização no exterior não significava necessariamente a perda da nacionalidade britânica. Este princípio foi primeiramente questionado durante a Revolução Americana. Na explosão da Revolução, cada habitante dos Estados norte-americanos teve a oportunidade de permanecer inglês ou obter a nacionalidade dos EUA. Atualmente, em geral, os sistemas legais nacionais prevêem a perda da nacionalidade em certas circunstâncias e a prática corrente dos Estados não aceita nenhuma regra geral proibindo tais medidas. Goodwill-Gill, International Law and the Movement of Persons Between States, 1978, p. 7. 158

Cosmopolitan Law Journal, v. 2, n. 1, jun. 2014, p. 131-167
} 
O direito de não adquirir uma nacionalidade foi também vastamente reconhecido, na medida em que a voluntariedade da aquisição reputa-se elemento basilar da moderna teoria da nacionalidade ${ }^{108}$.

O direito do indivíduo de não perder a nacionalidade é reconhecido até certo ponto. Alguns documentos internacionais mencionam o direito do indivíduo não ser privado arbitrariamente da sua nacionalidade ${ }^{109}$. A Convenção da ONU sobre a Redução da Apatrídia determina, em seu art.9o: "É vedado aos Estados Signatários privar qualquer indivíduo ou grupo de indivíduos de sua nacionalidade com base em razões raciais, étnicas, religiosas ou políticas". Ou seja, não é vedada a perda de nacionalidade, mas somente a perda por razões arbitrárias e/ou discriminatórias.

$\mathrm{O}$ direito de adquirir uma nacionalidade, por sua vez, não pode ser considerado, em termos gerais, um direito. Via de regra, os Estados são livres para conferir nacionalidade a quem quer que seja e, mesmo preenchidos todos os requerimentos legais previstos quanto à aquisição de nacionalidade, ainda assim a concessão da nacionalidade está, sob o ponto de vista internacional, na esfera da discricionariedade daquele Estado ${ }^{110}$.

Paul Weis, em seu trabalho sobre nacionalidade, estabeleceu determinados princípios que integram o direito internacional referente à nacionalidade. Em primeiro lugar, destaca-se o direito do nacional de um dado Estado de se estabelecer e residir no território deste Estado, que terá, portanto, o dever de aceitá-lo ${ }^{111}$. Como conseqüência, o Estado é também obrigado a readmitir seus nacionais vindos do exterior ${ }^{112}$. Weis defende que, em relação a ex-nacionais, que perderam a nacionalidade do Estado em questão, não existe, no entanto, regra de direito internacional que obrigue os Estados a readmiti-los ${ }^{113}$. Enfatiza, também, a idéia de que a aquisição da nacionalidade deve ser

${ }^{108}$ Ver Convenção sobre a Nacionalidade da Mulher, Montevidéu-1933; Convenção da ONU sobre Nacionalidade da Mulher Casada, de 1957, Convenção da ONU sobre a Eliminação de Todas as formas de Discriminação Contra as Mulheres, Nova York-1979, Declaração Americana, art. XIX. 109 Art. 20-3 da Convenção Americana; art. 15 (2) da Declaração Universal.

${ }^{110}$ A Declaração Americana, no art. XIX mencionou expressamente a discricionariedade ao prever o direito do indivíduo de mudar de nacionalidade para a nacionalidade de outro país que queira concede-la.

${ }^{111}$ Paul Weis, Nationality and Statelessness in International Law, 1956, p. 49.

112 Id. p. 53

${ }^{113}$ Idem p. 58 .dispondo de maneira inversa temos o Art. 1 do Protocolo Especial Relativo à Falta de Nacionalidade (Apatrídia) e o artigo 20 da Harvard Research on Nationality. 
voluntária ${ }^{114}$, e que o Estado tem o direito, em determinadas circunstâncias, de desnacionalizar certo indivíduo. Ressalta, ainda, que a desnacionalização é consectário do alistamento em serviço militar ou civil estrangeiro ou aceitação de distinções estrangeiras (incluindo a naturalização), saída ou estada no estrangeiro, condenação por certos crimes, atitudes ou atividades políticas ou em decorrência da segurança nacional ${ }^{115}$.

No tocante à sucessão universal dos Estados, Weis conclui que não existe regra em direito internacional segundo a qual o nacional de um Estado predecessor adquire a nacionalidade de um Estado sucessor. A despeito disto, via de regra, os Estados sucessores têm conferido suas nacionalidades aos antigos nacionais do predecessor ${ }^{116}$.

Relativamente à sucessão parcial, questões de nacionalidade serão normalmente reguladas por tratados ${ }^{117}$. Weis, no entanto, acentua a obrigação, ditada pelo direito internacional, do Estado predecessor retirar sua nacionalidade dos habitantes do território transferido ${ }^{118}$. Considerando questões de pluralidade de nacionalidades ele sugere aplicar, dentre duas nacionalidades, sempre a mais ativa e efetiva ${ }^{119}$.

O princípio da nacionalidade mais ativa ou mais efetiva já foi reconhecido várias vezes no direito internacional, além do citado caso Nottebohm. No caso Canevaro (Itália x Peru), decidido em 1912 pela Corte Permanente de Arbitragem ${ }^{120}$, o resultado sobre a questão da nacionalidade de um dos indivíduos envolvidos foi de crucial relevância ao desfecho do litígio.

Rafael Canevaro nasceu em território peruano e, dessa forma, conforme as leis peruanas, era reputado seu nacional. Ele, igualmente, era filho de pai italiano e, dessa forma, consoante as leis italianas, era também nacional daquele país. Até este ponto, tratava-se de simples questão de dupla nacionalidade. O governo italiano processou o governo peruano por questão envolvendo Canevaro, e a Corte decidiu que este último tinha o direito de considerá-lo seu nacional, principalmente porque, em inúmeras ocasiões, agiu como se fosse um nacional

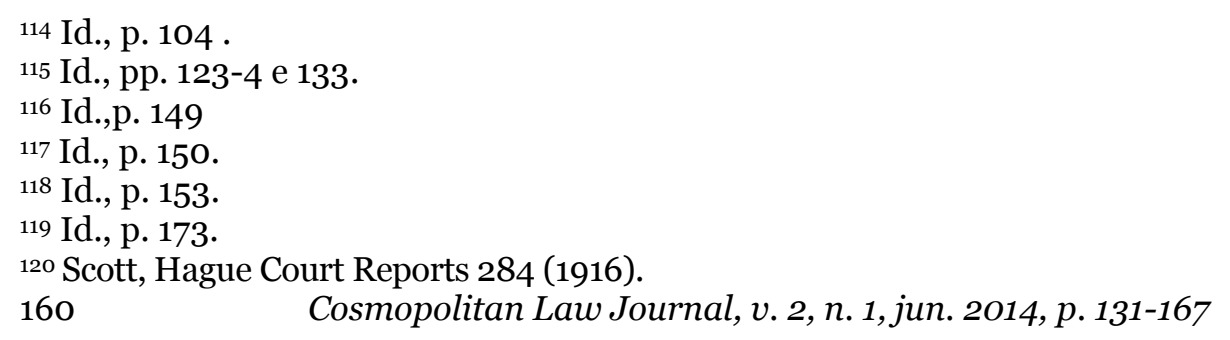


peruano, chegando, inclusive, a concorrer ao Senado Federal daquele país. Embora não haja colocado a questão sob este prisma, a Corte Permanente de Arbitragem considerou Canevaro peruano em virtude de sua estreita ligação com aquele país.

No mesmo sentido, recorde-se o caso Mergé ${ }^{121}$, onde a Sra. Mergé, nacional originária americana, pelo nascimento, era também nacional italiana em razão do casamento com um italiano. Os EUA apresentaram uma reclamação contra a Itália a favor da Sra. Mergé, baseando-se no Tratado de Paz Italiano de 1947. A Comissão recusou a reclamação com o pretexto de que Sra. Mergé não poderia ser tratada como nacional americana, haja vista ter vivido na Itália durante anos, ter sempre utilizado o passaporte italiano e, durante a guerra, não ter sido tratada e não ter se comportado como nacional dos EUA enquanto esteve na Itália.

Mais recentemente, como resultado do Acordo de Argel, entre a República Islâmica do Irã e os Estados Unidos da América, tendo como intermediária a República Popular e Democrática da Argélia, e que facilitou a libertação dos 52 nacionais norte-americanos detidos no Irã por 444 dias, foi estabelecido o Tribunal de Reclamações Irã-EUA, que objetivava decidir: (1) pretensões dos nacionais norte-americanos contra o Irã; (2) pretensões dos nacionais iranianos contra os EUA; (3) certas pretensões dos EUA e Irã contra cada um. O Acordo estabeleceu, em seu art. VII, I, que: "For the purposes of this agreement: a national of Iran or of the United States, as the case may be, means (a) a natural person who is a citizen of Iran or the United States....". ${ }^{122}$

Inúmeras reclamações, no entanto, foram apresentadas por indivíduos que possuíam dupla nacionalidade, iraniana e norte-americana. O tribunal teve então que decidir se tais pretensões seriam aceitas ou se violariam os termos do Tratado entre as partes e o direito internacional. Seis dos árbitros ${ }^{123}$ concordaram que essas reclamações deveriam ser aceitas, e o princípio da nacionalidade mais efetiva foi aplicado. A decisão foi baseada no fato que o tratado não implicava que a dupla nacionalidade seria excluída dos benefícios do acordo e o fato que o termo usado foi cidadão do Irã ou dos EUA e não nacional do Irã ou dos EUA. A ideia

${ }^{121}$ Estados Unidos da America ex rel. Florence S. Merge v. Italian Republic, Comissão Conciliadora Italiana Norte-americana, 1955.

122 Acordo de Argel, International Legal Materials, v. 20, 1981, p. 223.

123 O Tribunal consiste de nove árbitros, de acordo com o artigo III, 1, do Acordo. Três foram apontados pelos EUA, três pelo Irã e três foram escolhidos pelos seis árbitros. Os três árbitros apontados pelo Irã discordaram da decisão do Tribunal.

Revista de Direito Internacional do Programa de Pós-Graduação em Direito da UERJ 161 
de cidadania, como mencionada previamente, é inequivocamente um conceito de direito local, enquanto nacionalidade é um conceito de direito internacional. Desse modo, o termo pode ser entendido como o status do indivíduo em consideração ao direito de cada Estado ${ }^{124}$.

No entanto, todas essas regras de Direito Internacional referentes à nacionalidade têm um alcance bastante limitado. O efeito prático dessas regras é que as leis locais em violação ao Direito Internacional não serão reconhecidas por outros Estados, não terão nenhum efeito extraterritorial e não serão aplicadas nos tribunais internacionais. Paradoxalmente, contudo, o indivíduo, domesticamente, irá possuir a nacionalidade do Estado em questão, não importando o quão incongruente com o Direito Internacional esta nacionalidade possa ser.

\section{PRINCÍPIOS GERAIS LIMITANDO O PODER DOS ESTADOS EM QUESTÃO DE NACIONALIDADE}

Em resumo, algumas conclusões podem ser deduzidas quanto aos princípios básicos envolvendo a determinação da nacionalidade de um indivíduo em direito internacional:

(1) Cada Estado é habilitado para determinar quem são seus nacionais ${ }^{125}$.

(2) O Direito Internacional impõe algumas limitações ao poder do Estado de determinar quem são seus nacionais ${ }^{126}$.

(3) Nacionalidade não é um vínculo permanente. É possível que um nacional se torne estrangeiro ${ }^{127}$.

(4) Como corolário dos princípios anteriores, os Estados podem desnacionalizar os indivíduos, na medida em que haja clara previsão

\footnotetext{
124 International Legal Materials, v. 23, p. 489 (1984).

125 Convenção da Haia sobre Nacionalidade arts. 1 e 2; Código de Bustamante, Havana, 1928, ratificado por todos os Estados Americanos exceto os EUA, México, Colômbia, Argentina, Uruguai e Paraguai, arts. 9, 12, 14, 15; Declaração Americana, art. XIX; Harvard Draft on Nationality, 1929, art. 2; Decisão do PCIJ (1928), troca das populações grega e turca, Convenção Européia sobre Nacionalidade, art. $3^{\circ}, 1,1997$.

126 Convenção da Haia sobre Nacionalidade, art. 1; The Harvard Draft on Nationality,1929, art. 2; Nottebohn Case, CIJ, 1955; Convenção Européia sobre Nacionalidade, art. $3^{\circ}$, 2, 1997.

127 Declaração Americana art. XIX; Convenção Europeia sobre Nacionalidade, arts. $7^{\circ}$ e 8º 1997 ; Declaração Universal, art. XV.2. 
legal das hipóteses de destituição de nacionalidade, sem margem para a arbitrariedade ${ }^{128}$.

(5) Direito a uma nacionalidade - A grande maioria dos documentos internacionais de direitos humanos mencionam o direito à nacionalidade. No entanto, a aplicação prática dessas regras é objeto de debate. A interpretação mais apropriada do princípio é a que o considera como diretriz indicativa para os Estados ao legislarem sobre nacionalidade, no intuito de que se evite a apatrídia ${ }^{129}$. Ademais, deve ser levado em conta na aplicação das normas internas sobre aquisição e perda da nacionalidade, sempre se adotando uma interpretação favorável à manutenção da nacionalidade.

(6) Prevenção à Apatrídia - Como visto acima, face à relevância do vínculo da nacionalidade, a grande maioria das convenções internacionais tentam minimizar a possibilidade de sua ocorrência130.

(7) Apenas um nacional tem o direito de entrar, morar, locomover-se livremente e não ser expulso do território de determinado país. Como conseqüência, estrangeiros são, via de regra, privados desses direitos ${ }^{131}$.

(8) Também como conseqüência, nacionais de um Estado que tenham perdido a sua nacionalidade, na ausência de alternativas de destino, devem ser admitidos no Estado de sua última nacionalidade ${ }^{132}$.

${ }_{128}$ Declaração Universal, art. 15(1); Convenção Americana, art. 20 (1); Convenção Europeia sobre Nacionalidade, arts. $7^{\circ}$ e $8^{\circ}, 1997$; Declaração Universal, art. XV.2.

129 Ver Declaração Universal, art. 15(1); Convenção Americana, art. 20.1; Declaração Americana, art. 24 (3), Pacto Internacional sobre Direitos Civis e Políticos, art. 24, 3 (ONU-1966); Convenção sobre os Direitos da Criança (Nova York - 1989), art. 7; Convenção Européia, arts. 4, $a$ e $b$ 6.1, $b$, 7.3 e 8.1 .É necessário apontar que o direito a nacionalidade tem sido invocado em inúmeras jurisdições domésticas como o caso do Ministro Do Interior v. Kemali (Itália); Caso da Naturalização Iraniana (França), na esfera internacional no caso Nottebohm no voto dissidente do Juiz Guggenheim e também pela Corte Interamericana de Direitos Humanos nos casos Re Amendments to the Naturalization Provision of the Constitution of Costa Rica 5 HRLJ 161 (1984) todos citados por Johannes M. M. Chan, The Right to a Nationality as a Human Right, 12 Human Rights Law Journal, p. 3, nota 20. Ademais, a Suprema Corte norte-americana, no caso Afroyim $v$. Rusk 387 US 253 (1967), determinou que a Emenda 14 não permite que o Congresso retire a nacionalidade de um indivíduo que não consinta com isso.

${ }^{130}$ Ver Convenção da ONU sobre a Redução da Apatrídia, art.1; Convenção Americana, art.20.2; Convenção de Haia sobre Nacionalidade, arts.: 14 a 17; Harvard Draft on Nationality, art. 7 e 9; Convenção Européia, arts. 4.b, 6.1, b, 7.3 e 8.1.

${ }^{131}$ Declaração Universal, art. 13(2); Convenção Americana, art. 22.5, Declaração Americana, art. VIII; Quarto Protocolo à Convenção Europeia de Direitos Humanos, 1963, art. 3; Convenção sobre a condição dos estrangeiros (Havana - 1928).

${ }^{132}$ Harvard Draft on Nationality, art. 20; art. 1 do Protocolo Especial Relativo à Apatrídia. Como observado anteriormente, Paul Weis discorda que esta seja uma regra de direito internacional.

Revista de Direito Internacional do Programa de Pós-Graduação em Direito da UERJ $\quad 163$ 
(9) Nacionais têm o direito de deixar seu país ${ }^{133}$.

(10) O casamento não tem influência alguma na nacionalidade. Até recentemente, alguns Estados estabeleciam que uma nacional de determinado país perdia sua nacionalidade se casasse com um estrangeiro e, inversamente, quando uma mulher estrangeira se casasse com um nacional ela adquiriria automaticamente a nacionalidade do seu marido. Atualmente, entretanto, tem-se entendido que o casamento apenas tem o condão de facilitar o processo de aquisição de determinada nacionalidade ${ }^{134}$.

(11) Somente aos nacionais são atribuídos direitos políticos plenos ${ }^{135}$.

(12) Em casos de dupla nacionalidade, aplica-se o direito interno se uma das nacionalidades é a do Estado em questão ${ }^{136}$. Em caso contrário, aplica-se o princípio da "nacionalidade efetiva"137.

(13) Relativamente à aquisição da nacionalidade, filhos de pessoal diplomático constituem exceção à regra do “ius solis” e não adquirem a nacionalidade do país onde nasceram ${ }^{138}$.

(14) A aquisição derivada de nacionalidade deve ser voluntária139.

(15) As regras envolvendo nacionalidade devem ser estabelecidas por lei140.

133Declaração Universal, art. 13(2); Pacto Internacional sobre Direitos Civis e Políticos, art. 12.2, Quarto Protocolo à Convenção Europeia de Direitos Humanos, 1963, art. 2.

${ }_{134}$ Convenção da ONU sobre Eliminação de Todas as formas de Discriminação Contra as Mulheres (Nova York - 1979), art. 9.1; Convenção sobre a Nacionalidade da Mulher (Montevidéu - 1933) artigo 1 e a Convenção sobre a Nacionalidade da Mulher Casada, (Nova York - 1957); Convenção Europeia sobre Nacionalidade, art. 4.d especificamente; e em geral todas as previsões de não discriminação, que proíbem discriminações baseadas no sexo: art. 2 da Declaração Universal; art. 2.1 do Pacto Internacional sobre Direitos Civis e Políticos; art. 1(1) da Convenção Americana; art.5 da Convenção Europeia sobre Nacionalidade.

135 Declaração Universal, art.21(1), art.21(2); Pacto Internacional sobre Direitos Civis e Políticos, art. 25; Convenção Americana, art.23; Declaração Americana, art. XX, Convenção de Havana sobre Condição dos Estrangeiros, art. 7

${ }^{136}$ Convenção de Haia sobre Nacionalidade, art. 3; Código de Bustamante, art.9.

137 Código de Bustamante, art. 10, onde a nacionalidade efetiva é a do lugar de domicílio do indivíduo; Convenção da Haia sobre Nacionalidade, art. 5, no qual é exemplificado o princípio da residência habitual e principal ou "a nacionalidade do país, ao qual, segundo as circunstâncias, ele, de fato pareça mais ligado.

${ }^{138}$ Ver Harvard Draft on Nationality, art. 5; Convenção da Haia sobre Nacionalidade, art.12; Optional Protocol to the Vienna Convention on Diplomatic Relations, art. 2.

139Harvard Draft on Nationality, art. 15; Convenção da Haia sobre Nacionalidade, arts 10 e 11.

${ }^{140}$ Harvard Draft on Nationality, art. 2, Convenção da Haia sobre Nacionalidade, arts 1 e 2, Convenção Europeia sobre Nacionalidade, art. 3.1 
(16) As regras sobre nacionalidade não podem se basear em discriminação com base em sexo, religião ou raça ${ }^{141}$.

\section{REFERÊNCIAS}

ALEINIKOFF, T.A. \& MARTIN, D.A. Immigration: Process and Policy. St Paul, Minnesota: West Publishing \& Co., 1985.

AMERICAN LAW INSTITUTE. Restatement of the Law Third, The Foreign Relations Law of the US. (1987)

ARAÚJO, Nadia de. Perda e Reaquisição da Nacionalidade Brasileira. In: DOLINGER, Jacob (org.). A nova Constituição e o direito internacional. Rio de Janeiro: Freitas Bastos, 1987.

ARENDT, Hannah. The Origins of totalitarianism. Nova York: Harcourt, Brace \& World, 1966.

BAR-YAACOV, Nissim. Dual Nationality. Londres: Stevens \& Sons Ltd., 1961. BARROSO, Luis Roberto. Duas questões controvertidas sobre o direito brasileiro da nacionalidade. In: DOLINGER, Jacob (org.). A nova Constituição e o direito internacional. Rio de Janeiro: Freitas Bastos, 1987.

BISHOP, W. International Law: Cases and Materials, $3^{\text {a }}$ ed. Boston: Little, Brown \& Co., 1971.

BORCHARD, Edwin Montefiore. Diplomatic Protection of Citizens Abroad or the Law of International Claims. Nova York: The Banks law publishing co., 1916.

BRASIL. Ministério das Relações Exteriores. Manual do Serviço Consular e Jurídico, edição 2010. Disponível em: <http://sistemas.mre.gov.br/kitweb/ datafiles/Miami/pt-br/file/MSCJ-1.pdf>

CASSESE, Antonio. International law in a divided world. Nova York: Oxford, 1986.

CHAN, Johannes M.M. The Right to a Nationality as a Human Right. In: Human Rights Law Journal, vol. 12, 1991.

DEUTSCH, Karl W. Nationalism and its alternatives. Nova York: Knopf, 1969.

DOLINGER, Jacob. Direito internacional privado - Parte geral, $9^{\mathrm{a}}$ ed. Rio de Janeiro: Renovar, 2008.

DOLINGER, Jacob. Nottebohm revisited. In: CASELLA, Paulo Borba (org.). Dimensão internacional do direito- estudos em homenagem a G.E. do Nascimento e Silva. São Paulo: LTr, 2000.

DOLINGER, Jacob. Os Brasileiros Naturalizados no Poder Público. In: DOLINGER, Jacob (org.). A nova Constituição e o direito internacional. Rio de Janeiro: Freitas Bastos, 1987.

${ }^{141}$ Convenção Europeia sobre Nacionalidade, art. $5^{\circ}$, Convenção sobre Eliminação de todas as formas de discriminação racial, 1966, art. 3.1.

Revista de Direito Internacional do Programa de Pós-Graduação em Direito da UERJ 165 
GOODWILL-GRILL, Guy S. International Law and the Movement of Persons Between States. Oxford: Clarendon Press. 1978

GORDON, Charles e ROSENFIELD, Harry N. Immigration Law and Procedure.

HARVARD Research in International Law. Draft on Nationality. Supplement to the American Journal of International Law, v. 23, 1929. Disponível em: <http://www.uniset.ca/naty/maternity/23AJILSS13.pdf >.

HENKINS, Louis. Foreign Affairs and the Constitution. Nova York: Oxford University Press, 1996.

HINSLEY, F.H. Nationalism and the international system. Dobbs Ferry, N.Y.: Oceana Publications, 1973.

KELSEN, Hans. Principles of International Law, $2^{\text {a }}$ ed., revisada e editada por Robert W. Tucker. Nova York: Holt, Rinehart \& Winston, 1966.

KOHN, Hans. The idea of nationalism, 2a ed. Nova York: Collier Books, 1967.

LAGARDE, Paul. La nationalité française. Paris: Dalloz, 1975.

LAUTERPACHT, Hersch. International Law and Human Rights. Cambridge: Archon Books, 1968

MARINHO, Ilmar Penna, Tratado sobre a Nacionalidade: do direito brasileiro da nacionalidade. Rio de Janeiro: Imprensa Nacional, 1956.

MC DOUGAL, Myres S., CHEN, Lung-chu, e LASSWELL, Harold D. The Protection of Aliens from Discrimination and World Public Order: Responsibility of States Conjoined with Human Rights. In: American Journal of International Law, v. 70, 1978.

MCGOVNEY, Dudley O. Our Non-Citizen Nationals, Who are They? In: California Law Review, vol. 22, 1934. Disponível em: <http://scholarship.law.berkeley.edu/californialawreview/vol22/iss6/1>.

MELLO, Celso R. D. de Albuquerque. Curso de Direito Internacional Público, vol. II, 15 a ed. revista e ampliada. Rio de Janeiro: Renovar, 2004

MORAES, Alexandre de. Direito Constitucional, 24 a ed. São Paulo: Atlas, 2009.

MUTHARIKA, Peter. The Regulation of Statelessness under International and National Law, Texts and Documents. Dobbs Ferry, N.Y.: Oceana Publications, 1976.

OPPENHEIM, Lassa F.L. International law, a treatise, vol. I. Londres: Longmans, Green, and co., 1905.

OPPENHEIM, Lassa F.L. International law, a treatise, vol. I., $8^{\text {a }}$ ed. Londres: Longmans, Green \& Co. 1955.

ORAÁ, Jaime. Human Rights in States of Emergency in International Law. Oxford: Clarendon Press, 1996.

PHILLIMORE, Lord Walter G.F. Droits et Dévoirs des États. In: Récueil des cours de l'Académie de droit international de La Haye, vol. 1, 1923. 
PLENDER, Richard. International Migration Law, $2^{\text {a }}$ ed. Martinus Nijhoff, 1987.

REZEK, Francisco. Le droit international de la nationalité. In: Recueil des Cours de l'Académie du Droit International, v. 198, 1986.

RONZITTI, Natalino. Rescuing Nationals Abroad Through Military coercion and Intervention on Ground of Humanity. Dordrecht: Martinus Nijhoff, 1985 .

SCELLE, Georges. Précis de Droit des Gens.

SCOTT, James Brown. The Hague Court Reports. Nova York: Oxford University Press, 1916.

SILVA, José Afonso da. Curso de direito constitucional positivo, $32^{\mathrm{a}}$ ed. São Paulo: Malheiros, 2009.

TENÓRIO, Oscar. Direito Internacional Privado, v. I. Rio de Janeiro: Freitas Bastos, 1970

TIBURCIO, Carmen. Human rights of aliens under international and comparative law. Haia: Martinus Nijhoff, 2001.

VARGAS, Daniela Trejos. Atribuição da Nacionalidade Brasileira pelo critério do ius sanguinis ao filho de brasileiro nascido no exterior, à luz das modificações introduzidas pela Emenda Constitucional de Revisão $\mathbf{n}^{\circ} .3$ de 1994. Dissertação (mestrado). Rio de Janeiro: Pontifícia Universidade Católica do Rio de Janeiro, Departamento de Direito, 1997.

WEIS, Paul. Nationality and statelessness in international law. Nova York: Frederick A. Praeger, 1956.

ZEBALLOS, Estanislao Severo. La Nationalité, v. I. Paris: Sirey, 1914. 